\title{
Knowledge, Attitudes and Practices on the Use of Botanical Medicines in a Rural Caribbean Territory
}

Tatijana Vujicic and Damian Cohall *

Faculty of Medical Sciences, The University of the West Indies, Cave Hill, St. Michael, Barbados

The worldwide use of medicinal plant products has been steadily increasing over the past few decades, whereas the traditional knowledge and practices of these botanical medicines appears to be diminishing. Considering the need to conserve and document these traditions, the objective of this study was to understand the

Edited by: Michael Heinrich, UCL School of Pharmacy, United Kingdom

Reviewed by: Fabien Schultz, Technical University of Berlin,

Germany

Rebecca Lazarou, Royal Botanic Gardens, Kew,

United Kingdom

*Correspondence: Damian Cohall damian.cohall@cavehill.uwi.edu

Specialty section: This article was submitted to Ethnopharmacology,

a section of the journal

Frontiers in Pharmacology

Received: 24 May 2021 Accepted: 06 October 2021 Published: 27 October 2021

Citation:

Vujicic T and Cohall D (2021) Knowledge, Attitudes and Practices on the Use of Botanical Medicines in a

Rural Caribbean Territory.

Front. Pharmacol. 12:713855.

doi: 10.3389/fphar.2021.713855 knowledge, attitudes, and practices of people who are familiar with botanical medicines, as well as any factors that may influence the perceptions and behaviours associated with the use of medicinal plants. A previously validated survey instrument assessing knowledge, attitudes, and practices on the use medicinal plants was randomly administered to residents of three rural Barbadian communities. The data was analyzed using descriptive statistics and cross tabulations (Chi-Square Test, Fisher's Exact Test), with a confidence level of $95 \%$ and significance level of $p<0.05$. One hundred and fifty-four participants completed the survey with a response rate of 96\%. From participant responses we found that over $75 \%$ of the study population used botanical medicines. Key findings included a diverse repertoire of traditional knowledge on the use of medicinal plants, which included a total of 29 medicinal applications cited across 69 different plant species and 39 families. The most popular species among respondents (irrespective of use) were Pimenta racemosa (Mill.) J.W. Moore ( $F C=30, R F C=0.26)$, Momordica charantia $\mathrm{L}$. ( $F C=28, \mathrm{RFC}=0.24)$, Zingiber officinale Roscoe $(F C=22, R F C=0.19)$ and Annona muricata $\mathrm{L}$. ( $F C=21, \mathrm{RFC}=0.18)$. The findings also show the persistence of medico-cultural concepts such as cleansing and cooling, and identified significant associations between the use of botanical medicines and related practices with demographic variables such as education ( $p=0.05$; Fisher's Exact Test) and health insurance, $\chi^{2}(1, n=152)=4.645, p=0.003$. The findings of this study can be used in the identification and archiving of the medicinal plant practices in Barbados and the wider Caribbean, as well as for the larger purposes of biocultural exploration, preservation and further scientific assessment of botanical medicine practices.

Keywords: caribbean, drug-herb interaction, botanical, medicine, predictors, survey, medicinal plants 


\section{INTRODUCTION}

The Caribbean region is widely recognized for its rich plant diversity, ranking among the top 6 of 25 global biodiversity hotspots (Carrington, 2007; Cohall, 2014). These plants are utilized extensively throughout the Caribbean in the practice of folklore botanical medicine, which originated from the intense cultural convergence prompted by European colonialism, indigenous cultures of the Americas, the transatlantic slave trade, and immigration of indentured servants from Asia (Bayley, 1949; Feng 1956; Crawford-Daniel and Alexis, 2014). Many of the healing botanical medicines used in the Caribbean today are of West African origin, including the use of Citrus aurantiifolia [Christm.] Swingle (Lime), Ricinus communis L. (Castor Bean), and Abrus precatorius L. (Wild Licorice/Crab's Eye) (McCaskie, 2017). These were all important species used in West African healing traditions and are still commonly used in Caribbean countries such as Jamaica (Vandebroek and Picking, 2020), Cuba (Heredia-Diaz et al., 2018), the Virgin Islands (Soelberg et al., 2016), and others (Torres-Avilez et al., 2015). However, because of the cultural suppression and syncretism that occurred during the enslavement of West Africans in the Caribbean and after their emancipation, many of the islands differ in respect to their native pharmacopeias (Crawford-Daniel and Alexis, 2014; Sutherland et al., 2014).

Barbados is the easternmost Caribbean island and has a population of $287,000,95.5 \%$ of which are descendants of the enslaved West African people (World Development Indicators, 2019; Jackson et al., 2021). Approximately $65 \%$ of the healthcare in Barbados is public and 35\% private, however, the public system is universally accessible, free at delivery and, notably, includes access to drugs (Labonte et al., 2017). Despite this, the healthcare expenditure ranks high among other Caribbean or Central American countries, with an increase in disease burden on the island. One in ten Barbadian adults has a chronic, noncommunicable disease and the associated mortality rate per 100,000 is increasing (Unwin et al., 2015; Global Burden of Disease Collaborative Network, 2020). Additionally, noncommunicable diseases account for 9 of the top 10 causes of death in Barbados (Global Burden of Disease Collaborative Network, 2020).

Unlike its neighboring islands, Barbados was colonized primarily by the British and did not have the influx of indentured servants observed in other southern Caribbean islands (Lane, 1979). While a wealth of literature exists on traditional botanical medicine in larger Caribbean countries (Mahabir and Gulliford, 1997; Merritt-Charles, 2011; Clement et al., 2005), there is a need for more comprehensive studies to be done on this topic in smaller islands such as Barbados, as they were subject to a stronger degree of cultural suppression (Abrahams, 1967). For instance, smaller islands typically had smaller plantations, which meant fewer slaves and greater oversight from the plantation owners, as well as a greater adoption by slaves of the attitudes and expressions of the owners (Abrahams, 1967). This was especially the case amongst the liberated slaves who aspired for a better quality of life, which translated to attaining a British-based education, accessing westernised healthcare, and generally engaging in activities with the British colonial upper-class (Crawford-Daniel and Alexis, 2014). As a result, a gradient developed in the knowledge and use of traditional medicine between the uneducated vs educated, rural vs urban Barbadians (Crawford-Daniel and Alexis, 2014). Additionally, compared to the larger islands, more land mass had to be cultivated to ensure the plantation system was economically viable, which lead both to 1) the loss of hundreds of plant species across the island due to deforestation-many of which were potentially medicinal, and 2) newly freed slaves having few options but to remain on the plantations as labourers after the abolishment of slavery (Bayley, 1949; Watts, 1966; Abrahams, 1967). Currently, the island has approximately 650 species of flowering plants with only two species being endemic (Bayley, 1949; Carrington, 2007; Cohall, 2014). The persistence of many of these outcomes into present-day Barbados makes it a particularly compelling candidate for novel ethnopharmacological studies, as it not only provides information about local botanical medicine practices, but may also elucidate processes that underlie or drive the use of botanical medicine within the region, by allowing for comparisons with larger countries that did not experience the same degree of deculturation.

Even with the loss of some cultural practices and plant species throughout colonization, there are immense health and economic benefits associated with the cultivation, harvesting, extraction, research, and development of plant-based natural health products, as well as potential economic benefit in the marketing of Barbados and the broader Caribbean region as a health and wellness destination, addressing both spiritual and physical health. In fact, the medicinal uses of many of these plants have been investigated and confirmed mainly by in vitro and preclinical studies (Cohall, 2014). Therefore, substantial efforts should be made to document and preserve medicinal plant knowledge in the Caribbean and to identify barriers to use. Some such barriers may include the perceived superiority of western medical practices and the resultant attitudes of physicians towards botanical remedies, the possible effects of the unidentified chemical compounds in a plant, and the lack of public knowledge concerning drug-herb interactions.

Therefore, we conducted an observational study in College Lands, St. John, Barbados, to gain insight into the knowledge, attitudes, and practices on the use of botanical medicines in rural communities where the retention of these traditions has been reported to be higher (Crawford-Daniel and Alexis, 2014; Clement et al., 2015), and to determine whether there are factors that might predict or influence the use of these remedies in the surveyed communities. The knowledge gained from this research will be used to identify medicinal plants in the geographical area for further scientific investigation of pharmacological activity, cultivation, and the possible comodification into effective and commercially viable products, which may help to mitigate some of these main barriers to the use and access of the benefits of botanical medicines. 


\section{MATERIALS AND METHODS}

\section{Study Setting, Participants, and Ethics Approval}

Surveys were administered during April and May of 2018 in three rural communities situated in College Lands, a rural district in the parish of St. John located on the southeastern side of Barbados. These locations included the two communities adjacent to the Codrington College (Latitude/Longitude: $13^{\circ} 10^{\prime} 31^{\prime \prime} \mathrm{N} / 59^{\circ} 28^{\prime}$ $32^{\prime \prime} \mathrm{W}$ ) and College Savannah/Consett Bay (Latitude/Longitude: $\left.13^{\circ} 10^{\prime} 60.00^{\prime \prime} \mathrm{N} /-59^{\circ} 27^{\prime} 59.99^{\prime \prime} \mathrm{W}\right)$. These communities were the sugarcane-producing estates, Society and Consett. They were established in the 17th century by Christopher Codrington, who, after his death, left the estates to be used for the spiritual and physical well-being of people by developing a religious college - known today as Codrington College - while the surrounding lands were left for the people's livelihoods (Holder, 1988). This bequest was intended to benefit the nonWhite population of Barbados, including the provision of an education for those who were enslaved; however, slave labour in the estates continued until it was abolished in 1833 (Holder, 1988). This resulted in a unique convergence of slavery and education in an area with a plant biodiversity reflective of ancestral practices and the tropical climate associated with Barbados' geographical location (Carrington, 2007; CrawfordDaniel and Alexis, 2014).

A map of College Lands was used with census data provided by the administration of the Codrington College and its Trust to assist in locating the community boundaries and the participants. Residents were recruited via written correspondences and flyers which were distributed in the area prior distributing the survey. The survey was randomly administered to persons meeting the eligibility criteria, which required them to be residents of College Lands, St. John, Barbados and at least 18 years of age. The number of surveys administered was based on a sample size of 160 , which was calculated at a power of $80 \%$, confidence level of $95 \%$, confidence interval of $4 \%$, and a population size of 216 (as determined from a census conducted in 2018). Surveys were applied and analyzed per person interviewed.

Study approval was obtained from The University of the West Indies (UWI)/Barbados Ministry of Health Ethics Committee/ Institutional Review Board (IRB No. 180303-A), and informed consent was obtained prior to administering the survey.

\section{Survey Instrument}

Semi-structured interviews were conducted using a questionnaire designed to probe information regarding the knowledge, attitudes, and practices surrounding the use of botanical medicines, as well as demographic data such as age, gender, education, and annual income. A total of 23 questions were asked, including singleresponse, multiple-response, and skip logic types. All questions were nominal in nature, excluding age and annual income. This instrument was validated and used in a prior ethnopharmacological study on the island (Cohall et al., 2012). Participants were asked to report information including, but not limited to, any chronic conditions they suffer from, their use of plant-based remedies, the specific plants they use and what they are used for, where they source the medicinal plants from, where they acquired their knowledge of botanical medicine, whether they discuss their use of plant-based remedies with their physician, as well as other nonbotanical medicine-related prompts. The survey instrument can be found in Supplementary Data Sheet 1.

\section{Plant Collection/Identification}

Where possible, field officers collected samples of plants which were identified by a plant taxonomist, and vouchered samples were deposited at the herbarium at The University of the West Indies, Cave Hill Campus. In some instances, plants were easily identifiable as crop plants and some recalled as semi-processed products. Lastly, some plants with reported medicinal properties were identified with the use of high resolution pictures from peerreviewed published sources by the interviewers. The scientific nomenclature of all the plant families and species were verified using the Kew Medicinal Plant Name Services (MPNS) and the final list of plants was reviewed by the plant taxonomist for accuracy.

\section{Data Analysis Measures}

For the purposes of this study, botanical medicine use was determined through participants' response to the survey question asking "do you use herbs/bush to treat? If no, skip to question 19." Those citing one or more plants that they personally use in a healing capacity were considered users of botanical medicines and are referred to as "users" in following sections. Those who skipped questions 12-18 were considered "non-users" and referred to as such.

In relation to the primary research question, the knowledge, attitudes, and practices were ascertained through data provided by the users of botanical medicine on the following variables:

- Specific medicinal plants employed in treatment

- Uses/applications of the medicinal plants

- Sources of botanical medicine knowledge

- Sources of medicinal plants

- Communication with doctor about botanical medicine use

- Behaviours and knowledge surrounding drug-herb combination and associated risks

- Recommendation of botanical medicines to others

In relation to the secondary research question, potential predictors of botanical medicine use were identified through cross-tabulation and significance testing of the following variables with "Use of Botanical Medicine" (Y/N):

- Age

- Education Level

- Income

- Physician Relationship

- Parental Use of Botanical Medicine

- Health Insurance $(\mathrm{Y} / \mathrm{N})$

A manual double data entry process was used to enter, verify, and validate the accuracy of data in Microsoft Excel (Microsoft 
Corporation, Redmond, Washington, United States). All data analysis was performed using SPSS 27 software (SPSS Inc., Chicago, Illinois, United States). The response options for each question were numerically coded beginning at a value of 1 . Missing values were assigned a code of " 888 ", “999", or were left as "system missing". 888 codes corresponded to "not applicable" and were assigned if the missing value was from participants who did not identify with the subset of respondents that the question was intended for, and thus were correct in skipping it. 999 codes were labelled "no response" and were used if the missing value was from participants who incorrectly skipped a question that was intended for their specific demographic (e.g., only answers one of a two-part question about their chronic condition). When values were missing from stand-alone questions (e.g., what is your age), they were considered "missing at random" and were left as such.

Ethnobotanical data concerning reported plant species and medicinal uses among the study population were analyzed using the following indices:

\section{Use Value}

The use value determines the therapeutic versatility of locally known plant species and was calculated using the following formula (Napagoda et al., 2018; Andriamparany et al., 2014; Phillips and Gentry, 1993):

$$
\mathrm{UV}=\frac{\Sigma \mathrm{Ui}}{\mathrm{N}}
$$

where $\mathrm{Ui}$ is the number of uses reported by each informant for a given species and $\mathrm{N}$ is the total number of informants. A high use value indicates that the cited species has a diversity of medicinal applications among the participants in the study.

\section{Frequency of Citation and Relative Frequency of Citation}

The frequency of citation is the number of informants reporting the use of a particular species, while the relative frequency of citation illustrates the local importance of each species among the study's participants and is given by the following formula (Amjad et al., 2017):

$$
\mathrm{RFC}=\frac{\mathrm{FC}}{\mathrm{N}}
$$

where FC is the frequency of citation (number of informants reporting the use of a particular species), and $\mathrm{N}$ is the total number of informants. This index varies from 0 , when nobody cited the use of the plant, to 1 in the case that all informants reported using this species.

All other data (e.g., demographic variables) were summarized using frequencies and percentages. To identify significant associations between variables, contingency tables were created, and Chi-squared analysis was performed. When more than 5 cells had an expected count less than 5 , the variables were either recategorized into larger groups, or the Fisher's Exact Test was used instead of the Chi-squared analysis. If an association was found to have statistical significance $(p \leq 0.05)$, a Z-test of column proportions with Bonferroni correction was carried out to highlight the specific relationships responsible for the significant result. Effect size was measured using Phi (for $2 \times$ 2 tables) or Cramer's V (for RxC tables).

\section{RESULTS}

\section{Characteristics of Sample}

A total of 154 completed questionnaires were obtained from residents of College Lands, St. John, Barbados with a response rate of $96 \%$. The median age group of respondents was $51-60$ years old $(n=31,20.1 \%)$, with $58.4 \%$ of the sample identifying as female and $41.6 \%$ identifying as male. Secondary school was the highest level of education attained by $45.4 \%$ of respondents, $30.9 \%$ had no higher than a primary level education, and $23.7 \%$ had attained an associate degree or higher. Among 136 total respondents, the most reported income range was less than $\$ 8,000$ BDS per year $(n=48,35.3 \%)$ followed by those earning greater than $\$ 28,000$ BDS per year $(n=30,22.6 \%) .62 .1 \%$ of participants $(n=95)$ had at least one chronic condition, the most common of which were Hypertension $(n=57,60.0 \%)$, Type II Diabetes Mellitus $(n=26,27.4 \%)$, and Arthritis $(n=24,25.3 \%)$. The treatment of chronic conditions with prescription medication was reported by 68 of the respondents, however, data was missing for 26 respondents. Participant characteristics are documented in Table 1, and data pertaining to the chronic conditions reported by participants are given in Table 2 .

\section{Knowledge, Attitudes, and Practices Surrounding the Use of Botanical Medicines}

Results presented in Characteristics of the Users of Botanical Medicines, Plants Used for Medicinal Purposes, Acquisition of Knowledge and Sources of Medicinal Plants, Discussion of Botanical Medicine Use with Doctor, Concomitant Use of Medicinal Plants and Prescription Medication, and Recommendation of Botanical Medicines to Others only pertain to data collected from users of botanical medicines, or simply "users".

\section{Characteristics of the Users of Botanical Medicines}

Out of the 154 survey respondents, 116 (75.3\%) were users of botanical medicines. The majority of the persons were over 50 years old $(62.1 \%)$, female (56.9\%), had "good" self-perceived health (51.7\%), and reported at least one chronic condition (62.1\%). Characteristics of the users are provided in Table 1.

\section{Plants Used for Medicinal Purposes}

As a group, the respondents cited a total of 29 different therapeutic applications across 69 different plants. The FC and RFC indices determined that Pimenta racemosa (Mill.) J.W. Moore (Bay Leaf), Momordica charantia L. (Cerasee), Zingiber officinale Roscoe (Ginger), Annona muricata L. (Soursop), Moringa oleifera Lam. (Moringa), Cymbopogon citratus (DC.) Stapf (Lemongrass), Aloe vera (L.) Burm.f. (Aloe), Persea americana Mill. (Pear), Petroselinum crispum (Mill.) Fuss (Parsley) and Azadirachta indica A. Juss. (Neem), were the 10 most cited ethnomedicinal plant species (Table 3) with reference to the respondents who cited the use of these plant species. In terms 
TABLE 1 | Participant characteristics.

Total N (\%)

$5(3.2)$
$13(8.4)$
$20(13.0)$
$23(14.9)$
$31(20.1)$
$29(18.8)$
$30(19.5)$

$3(1.9)$
$64(41.6)$

$90(58.4)$
Proportion using botanical medicines

$n / \mathrm{N}$ $\%$

\section{Age (Years)}

$<20$
$21-30$
$31-40$
$41-50$
$51-60$
$61-70$
$71-80$
$81-90$

Gender

Male

Female

Education Leve

Primary or less

Secondary

Associate/Nocational

Undergraduate

Graduate

(Missing values)

Missing at random

Annual Income (BDS) ${ }^{a}$

Less than $\$ 8,000$

$\$ 8,000-\$ 13,000$

$\$ 13,000-\$ 18,000$

$\$ 18,000-\$ 23,000$

$\$ 23,000-\$ 28,000$

$\$ 28,000+$

Retired

(Missing values)

Missing at random

Relationship Status

Married

Single

Separated

Divorced

Widowed

Common-Law

Country of Birth

\section{7 (30.9) \\ $69(45.4)$ \\ $22(14.5)$ \\ 6 (3.9) \\ 8 (5.3)}

(2)

$\begin{array}{cc}2 / 5 & 40.0 \\ 8 / 13 & 61.5 \\ 17 / 20 & 85.0 \\ 17 / 23 & 73.9 \\ 24 / 31 & 77.4 \\ 24 / 29 & 82.8 \\ 21 / 30 & 70.0 \\ 3 / 3 & 100.0\end{array}$

$50 / 64 \quad 78.1$

$\begin{array}{ll}66 / 90 & 73.3\end{array}$

$41 / 47$

87.2

$52 / 69 \quad 75.4$

$13 / 22$

$4 / 6$

$5 / 8$

59.1

66.7

62.5

(1)

$$
\begin{gathered}
45(33.8) \\
18(13.5) \\
10(7.5) \\
15(11.3) \\
12(9.0) \\
30(22.6) \\
3(2.3)
\end{gathered}
$$

\section{$34 / 45$}

$14 / 18$

$10 / 10$

$13 / 15$

$7 / 12$

$19 / 30$

$2 / 3$

(17)

(21)

$\begin{array}{cc}33 / 44 & 75.0 \\ 60 / 83 & 72.3 \\ 7 / 7 & 100.0 \\ 6 / 6 & 100.0 \\ 6 / 9 & 66.7 \\ 4 / 5 & 80.0\end{array}$

\section{4 (28.6)}

83 (53.9)

7 (4.5)

6 (3.9)

9 (5.8)

5 (3.2)

$4 / 5$

75.6

\begin{tabular}{|c|c|c|c|}
\hline Barbados & $147(95.5)$ & $111 / 145$ & 76.6 \\
\hline Other Caribbean Country & $7(4.5)$ & $5 / 7$ & 71.4 \\
\hline \multicolumn{4}{|l|}{ Self-Perceived Health } \\
\hline Excellent & $9(5.9)$ & $8 / 9$ & 88.9 \\
\hline Very Good & $29(19.0)$ & $21 / 29$ & 72.4 \\
\hline Good & $81(52.9)$ & $60 / 81$ & 74.1 \\
\hline Fair & $29(19.0)$ & $24 / 29$ & 82.8 \\
\hline Poor & 5 (3.3) & $3 / 5$ & 60.0 \\
\hline \multicolumn{4}{|l|}{ (Missing values) } \\
\hline Missing at random & (1) & & \\
\hline \multicolumn{4}{|l|}{ Chronic Condition } \\
\hline Yes & $95(62.1)$ & $72 / 95$ & 75.8 \\
\hline No & $58(37.9)$ & $43 / 58$ & 74.1 \\
\hline \multicolumn{4}{|l|}{ (Missing values) } \\
\hline Missing at random & (1) & (1) & \\
\hline
\end{tabular}

77.8

100.0

86.7

58.3

63.3

66.7

(Continued on following page) 
TABLE 1 | (Continued) Participant characteristics.

\begin{tabular}{|c|c|c|c|}
\hline & \multirow[t]{2}{*}{ Total N (\%) } & \multicolumn{2}{|c|}{ Proportion using botanical medicines } \\
\hline & & $n / N$ & $\%$ \\
\hline \multicolumn{4}{|c|}{ Parental Use of Botanical Medicines } \\
\hline Yes & $70(56.5)$ & $58 / 70$ & 82.9 \\
\hline No & $54(43.5)$ & $37 / 54$ & 68.5 \\
\hline \multicolumn{4}{|l|}{ (Missing values) } \\
\hline Missing at random & $(30)$ & $(21)$ & \\
\hline \multicolumn{4}{|l|}{ Health Insurance } \\
\hline Yes & $24(15.8)$ & $14 / 24$ & 58.3 \\
\hline No & $128(84.2)$ & $101 / 128$ & 78.9 \\
\hline \multicolumn{4}{|l|}{ (Missing values) } \\
\hline Missing at random & $(2)$ & (1) & \\
\hline \multicolumn{4}{|l|}{ Type of Healthcare } \\
\hline Public & $51(35.9)$ & $43 / 51$ & 84.3 \\
\hline Private & $71(50.0)$ & $47 / 71$ & 66.2 \\
\hline Both & $20(14.1)$ & $15 / 20$ & 75.0 \\
\hline \multicolumn{4}{|l|}{ (Missing values) } \\
\hline Missing at random & $(12)$ & & \\
\hline
\end{tabular}

${ }^{a_{1}} B D S=0.5$ USD

of the medicinal uses reported for these plants, the UV index identified $A$. indica as the most versatile species $(\mathrm{UV}=1.54)$, followed by $M$. charantia $(\mathrm{UV}=1.32), A$. vera $(1.24), P$. racemosa (1.17), A. muricata (1.14) and Zingiber officinale Roscoe (1.14), P. americana (1.13), C. citratus (1.11), M. oleifera (1.06) and $P$. crispum (1.06) among the reported citations. Irrespective of plant species, the most common therapeutic applications cited by respondents included "maintenance of health" $(n=49)$, "cooling" $(n=34)$, "hypertension" $(n=23)$, "cough" $(n=23)$, and "cold/flu" $(n=18)$. Table 3 lists all of the plants cited by participants, along with their uses, methods of administration, and FC, RFC, and UV scores.

\section{Acquisition of Knowledge and Sources of Medicinal Plants}

For most of the respondents $(n=92)$, botanical medicine knowledge was acquired from family members. Friends were the second most frequent source of knowledge $(n=41)$, followed by the internet $(n=21)$, books $(n=11)$, and colleagues $(n=5)$. Pharmacists, the elderly, and a health and beauty company were cited by only one respondent each. None of the respondents reported acquiring any knowledge from doctors.

Most respondents $(n=79)$ retrieved medicinal plants from their backyard, although they were also commonly acquired from friends $(n=28)$, family $(n=20)$ and, to a lesser extent, natural product shops $(n=13)$ and the supermarket $(n=13)$. Only one respondent obtained medicinal plants from the pharmacy. Other sources cited by respondents included the community $(n=2)$, town $(n=2)$, gully $(n=2)$, market $(n=1)$, and neighbours $(n=1)$. Figure 1 provides the specific plants acquired from each source.

Significant associations were found between the acquisition of knowledge and the source of medicinal plants. Respondents who acquired botanical medicine knowledge from family members were significantly more likely to source their medicinal plants from family than those who did not learn from their family members (22.5 vs $0.0 \%$ ) ( $p=0.02$; Fisher's Exact Test) (Table 4). Similarly, respondents who acquired their knowledge from friends were significantly more likely to source medicinal plants from friends compared to those who learned from other sources $(41.7$ vs $18.1 \%), \chi^{2}(1, n=108)=6.967$, $p=0.008$ ) (Table 5). The respective effect sizes were 0.22 (Phi) and 0.25 (Phi).

The source of medicinal plants was also significantly associated with education, and with annual income. Participants with a primary level education were more likely to acquire medicinal plants from their backyard than were people with a secondary level education (89.5 vs 61.7\%) ( $p=0.02$; Fisher's Exact Test) (Table 6), and participants earning over $\$ 18,000$ per year were more likely to acquire the plants from their family members compared to those earning less than $\$ 18000$ BDS per year (29.4 vs $10.7 \%), \chi^{2}(1, n=90)$ $=5.060, p=0.02)$ (Table 7). The effect sizes were 0.28 (Cramer's V) and -0.24 (Phi), respectively.

\section{Discussion of Botanical Medicine Use With Doctor}

Of the 103 users for which valid data were available, 80 (77.7\%) indicated that they do not discuss the use of botanical medicines with their doctor. Most respondents who had discussed this topic with their doctor also reported them as having a positive attitude towards it $(n=15,62.5 \%)$.

\section{Concomitant Use of Medicinal Plants and Prescription Medication}

Out of the 104 users with valid responses, 32 (30.8\%) reported using medicinal plants alongside prescription drugs, while the remaining $72(69.2 \%)$ did not combine the two. Reasons for abstaining were provided by 33 participants: 18 (54.5\%) cited 
TABLE 2 | Chronic Conditions and Drugs Prescribed for their Management Among Participants.

\begin{tabular}{|c|c|c|c|c|c|c|}
\hline \multirow{2}{*}{$\begin{array}{l}\text { Chronic } \\
\text { Conditions ( } \mathbf{N}=\mathbf{9 5}) \\
\text { Type II Diabetes }\end{array}$} & \multirow{2}{*}{$\begin{array}{c}n(\%) \\
26(27.4)\end{array}$} & \multirow{2}{*}{$\begin{array}{c}\text { Proportion (\%) using } \\
\text { Botanical Medicines } \\
22 / 26(84.6)\end{array}$} & \multicolumn{2}{|l|}{ Drugs Prescribed, $n$} & \multicolumn{2}{|c|}{$\begin{array}{l}\text { Reported Costs } \\
\text { (BDS) }^{\mathrm{a} n}\end{array}$} \\
\hline & & & Gliclazide & 9 & Free & 6 \\
\hline & & & Metformin & 14 & Free & 8 \\
\hline & & & Insulin & 7 & Free & 2 \\
\hline & & & & & $\$ 27.5 / \mathrm{m}^{\mathrm{b}}$ & 1 \\
\hline & & & Candesartan & 1 & Free & 1 \\
\hline & & & Sitagliptin-Metformin & 2 & $\$ 104 / m$ & 2 \\
\hline \multirow[t]{2}{*}{ Heart Disease } & $3(3.2)$ & $2 / 3(66.7)$ & Bisoprolol & 2 & - & - \\
\hline & & & Verapamil & 1 & Free & 1 \\
\hline \multirow[t]{15}{*}{ Hypertension } & $57(60.0)$ & $43 / 57$ (75.4) & Valsartan & 13 & Free & 6 \\
\hline & & & Amlodipine & 7 & Free & 2 \\
\hline & & & & & $\$ 30 / \mathrm{m}$ & 1 \\
\hline & & & Chlorthalidone & 2 & Free & 1 \\
\hline & & & Telmisartan & 3 & $\$ 40 / m$ & 2 \\
\hline & & & Aspirin & 2 & Free & 1 \\
\hline & & & Indapamide & 4 & Free & 2 \\
\hline & & & Bezide (Gliclazide-Metformin) & 3 & Free & 2 \\
\hline & & & & 5 & Free & 2 \\
\hline & & & Atenolol & & $\$ 21 / \mathrm{m}$ & 1 \\
\hline & & & Verapamil & 1 & Free & 1 \\
\hline & & & Lisinopril & 1 & Free & 1 \\
\hline & & & Indapamide-Amlodipine & 4 & Free & 3 \\
\hline & & & & & Free & 2 \\
\hline & & & Valsartan-Hydrochlorothiazide & 6 & $<\$ 20 / \mathrm{m}$ & 1 \\
\hline \multirow[t]{5}{*}{ High cholesterol } & $16(16.8)$ & 13/16 (81.3) & Atorvastatin & 10 & Free & 7 \\
\hline & & & Amlodipine & 1 & Free & 1 \\
\hline & & & Simvastatin & 1 & Free & 1 \\
\hline & & & Rosuvastatin & 1 & Free & 1 \\
\hline & & & Ezetimibe-Simvastatin & 1 & - & - \\
\hline \multirow[t]{2}{*}{ Back pain } & $11(11.6)$ & $8 / 11(72.7)$ & Acetaminophen & 3 & Free & 2 \\
\hline & & & & & $\geq \$ 5$ & 1 \\
\hline \multirow[t]{12}{*}{ Arthritis } & $24(25.3)$ & 19/24 (79.2) & Diclofenac & 3 & $\$ 6$ & 1 \\
\hline & & & Acetaminophen & 5 & Free & 2 \\
\hline & & & Carbamazepine & 1 & Free & 1 \\
\hline & & & Enalapril & 1 & - & - \\
\hline & & & Indapamide & 1 & - & - \\
\hline & & & Tramadol & 1 & Free & 1 \\
\hline & & & Glucosamine & 1 & Free & 1 \\
\hline & & & Methotrexate & 2 & - & - \\
\hline & & & L-ascorbic Acid & 1 & - & - \\
\hline & & & Ferrous Sulphate & 2 & - & - \\
\hline & & & Folic Acid & 2 & - & - \\
\hline & & & Omega 3 & 1 & Free & - \\
\hline \multirow[t]{3}{*}{ Osteoporosis } & $1(1 / 1)$ & 0 & Strontium Ranelate & 1 & - & - \\
\hline & & & Folic acid & 1 & - & - \\
\hline & & & Calcium Carbonate & 1 & - & - \\
\hline Sinus & $6(6.3)$ & 6/6 (100.0) & Nasal spray & 2 & Free & 2 \\
\hline \multirow[t]{6}{*}{ Asthma } & $7(7.4)$ & 4/7 (57.1) & Albuterol & 5 & Free & 3 \\
\hline & & & Betamethasone & 1 & $\$ 15$ & 2 \\
\hline & & & Fluticosone Proprionate-Salmaterol Xinafoate & 1 & $\$ 20$ & 1 \\
\hline & & & Beclometasone Diproprionate & 1 & Free & 1 \\
\hline & & & Budesonide-Formoterol & 1 & Free & 1 \\
\hline & & & & & Free & 1 \\
\hline \multirow[t]{3}{*}{ Neuro/Psychiatric } & $3(3.2)$ & 0 & Citalopram & 1 & - & - \\
\hline & & & Carbamazepine & 1 & - & - \\
\hline & & & Zolpidem & 1 & - & - \\
\hline Heart & $2(2.1)$ & 2/2 (100.0) & Warfarin & 1 & - & - \\
\hline Dyspnea & $1(1.1)$ & $1 / 1(100.0)$ & - & - & - & - \\
\hline \multirow[t]{2}{*}{ Blood/Circulatory } & $4(4.2)$ & $2 / 4(50.0)$ & Diosmin & 1 & $\$ 5 / \mathrm{m}$ & 1 \\
\hline & & & Ferrous sulphate & 1 & - & - \\
\hline Eye & $2(2.1)$ & $1 / 2(50.0)$ & Bimatoprost & 1 & - & - \\
\hline & & & Dorzolamide-timolol & 1 & $\$ 90$ & 1 \\
\hline Cancer & $2(2.1)$ & $1 / 2(50.0)$ & Cyproterone & 1 & - & - \\
\hline & & & & & ed on follo & \\
\hline
\end{tabular}


TABLE 2 | (Continued) Chronic Conditions and Drugs Prescribed for their Management Among Participants.

\begin{tabular}{|c|c|c|c|c|c|c|}
\hline \multirow{2}{*}{$\begin{array}{l}\text { Chronic } \\
\text { Conditions }(N=95) \\
\text { Thyroid }\end{array}$} & \multirow{2}{*}{$\begin{array}{l}\boldsymbol{n}(\%) \\
7(7.4)\end{array}$} & \multirow{2}{*}{$\begin{array}{c}\text { Proportion (\%) using } \\
\text { Botanical Medicines } \\
\qquad 4 / 7(57.1)\end{array}$} & \multicolumn{2}{|l|}{ Drugs Prescribed, $n$} & \multicolumn{2}{|c|}{$\begin{array}{l}\text { Reported Costs } \\
\quad(B D S)^{a} n\end{array}$} \\
\hline & & & Levothyroxine & 7 & Free & 2 \\
\hline & & & Calcium carbonate & 1 & $\$ 12 / m$ & 1 \\
\hline & & & & & $\$ 5$ & 1 \\
\hline & & & & & - & - \\
\hline Autoimmune & $1(1.1)$ & 1/1 (100.0) & - & - & - & - \\
\hline Kidney & $1(1.1)$ & 1/1 (100.0) & - & - & - & - \\
\hline GERD & $2(2.1)$ & 2/2 (100.0) & Omeprazole & 1 & $\$ 18$ & 1 \\
\hline
\end{tabular}

${ }^{a_{1}} B D S=0.5$ USD

${ }^{b} m$ is the abbreviation for month.

interaction effects, 9 (27.3\%) didn't take prescription medication at all, $3(9.1 \%)$ believed botanical medicines to be the superior treatment, $2(6.1 \%)$ wanted to ascertain the efficacy of botanical medicines alone, and $1(3.0 \%)$ reported taking them each at different times. In terms of risk awareness, $40 \%$ of respondents $(n=28)$ reported being aware of the possible risks associated with herb-drug interactions.

Concomitant use of medicinal plants and prescription drugs was significantly less practiced among participants whose parents are users of botanical medicines $(80.0$ vs $60.6 \%) \chi^{2}(1, n=88)=$ $3.911, p=0.05$, as well as among participants with no chronic conditions $(88.2$ vs $59.4 \%) \chi^{2}(1, n=103)=8.831, p=0.003$ (Table 8). The respective effect sizes were 0.21 (Phi) and 0.29 (Phi). Additionally, concomitant use was more frequent among respondents who did not discuss botanical medicines with their doctors $(n=19)$ than among those who did discuss with their doctors $(n=11)$, however, this result was marginally insignificant $(26.8$ vs $47.8 \%) \chi^{2}(1, n=94)=3.548, p=0.06$.

\section{Recommendation of Botanical Medicines to Others}

$88.3 \%$ of respondents $(n=88)$ reported that they would recommend the use of botanical medicines to someone else.

\section{Predictors of Medicinal Plant Use}

A significant association was found between education and medicinal plant use. Respondents with a primary level education were significantly more likely to use medicinal plants compared to those with an associate/vocational degree (87.2 vs $59.1 \%)(p=0.05$; Fisher's Exact Test) (Table 9). The effect size was 0.2 (Cramer's V).

Health insurance was also significantly associated with medicinal plant use. Participants who did not have health insurance were more likely to use medicinal plants than those with insurance $(58.3$ vs $78.9 \%) \chi^{2}(1, n=152)=4.645, p=0.03$ (Table 9). The effect size was -0.2 (Phi).

Medicinal plant use was more frequently reported by respondents whose parents also use medicinal plants $(n=58)$, compared to those whose parents do not $(n=37)$; however, this result was marginally insignificant $(82.9$ vs $68.5 \%) \chi^{2}(1, n=124)=3.498, p=0.06$.

No significant relationships were found between the use of medicinal plants and age ( 55.6 vs $79.1 \%$ vs 80.0 vs $72.7 \%$; $p=0.19$, Fisher's Exact Test), annual income ( 75.0 vs $85.7 \%$ vs 74.1 vs $\left.63.3 \% ; \chi^{2}[1, n=133]=3.825, p=0.28\right)$, nor physician relationship ( 74.6 vs $86.7 \%$; $p=0.52$, Fisher's Exact Test).

\section{DISCUSSION}

The primary purpose of this study was to determine the extent of use of botanical medicines by persons residing in three rural communities in College Lands, St. John, Barbados, and to gain insight into the knowledge, attitudes, and practices surrounding plant-based medicines in this locale. Secondary to this was the identification of potential factors that may influence the use of botanical medicines in that geographical location. The survey determined that over $75 \%$ of the study participants used plants for medicinal purposes, with the majority being female and over the age of 50. A diverse repertoire of medicinal plant knowledge was identified, both in terms of the specific plants used by respondents, as well as the multitude of conditions for which these plants were used. A total of 69 plant species belonging to 39 botanical families were reported, the most dominant being Lamiaceae ( 6 species) and Asteraceae ( 5 species). The high prevalence of botanical medicine use is expected considering the rural location of the study and thus these findings cannot be generalized to the whole population. In fact, other studies conducted in Barbados found that only 30\% of the whole Barbados population uses botanical medicines (Cohall et al., 2012; Peter, 2013). The low prevalence reported in these studies could partly be explained by the widespread adoption of Western medicine and practices, but could also be related to the deforestation that occurred in Barbados to make space for sugar cane plantations, which ultimately caused the number of plant species to diminish significantly and thus left few species to be used medicinally (Bayley, 1949). P. racemosa (Bay Leaf), M. charantia (Cerasee), Zingiber officinale Roscoe (Ginger), and A. muricata (Soursop) were the most frequently cited plants and were among those with the highest UV scores, indicating both the local importance and therapeutic versatility of these species within the study's population at the time of the survey. Although recent ethnobotanical studies are generally lacking in Barbados, a survey conducted in 2013 found similar results regarding the plant species used by participants and their medicinal applications (Peter, 2013). This study identified 93 plant species that were cited as useful, and approximately $41 \%$ of those species were common to those identified in this survey. Many of the same use reports for plant species were highlighted in both surveys, such as the use of $A$. indica (Neem) for diabetes and hypertension, or Kalanchoe pinnata [Lam.] Pers. (Wonder-of-the-World) for cough, colds/flu, and cleansing. However, our study highlighted novel use 
TABLE 3 | List of medicinal plants, preparation methods and frequency of administration reported by users $(N=116)$.

\begin{tabular}{|c|c|c|c|c|c|c|c|c|}
\hline \multicolumn{4}{|l|}{ Plant } & \multirow{2}{*}{$\begin{array}{c}\text { FC } \\
\text { (RFC) }\end{array}$} & \multirow[t]{2}{*}{ UV } & \multicolumn{3}{|c|}{ Applications } \\
\hline Family & Species & $\begin{array}{l}\text { Voucher } \\
\text { No. }\end{array}$ & Local Name(s) & & & $\begin{array}{l}\text { Reported } \\
\text { Uses }\end{array}$ & $\begin{array}{l}\text { Preparation and } \\
\text { Administration }\end{array}$ & $\begin{array}{l}\text { Freq. of } \\
\text { Treatment }\end{array}$ \\
\hline \multirow[t]{2}{*}{ Acanthaceae } & Justicia secunda Vahl & & Bloodroot & $2(0.02)$ & 1.0 & Cleansing & Root (dried); decoction & Monthly \\
\hline & & & & & & Cold/Flu & Root (dried); decoction & As needed \\
\hline \multirow[t]{6}{*}{ Amaryllidaceae } & Allium sativum $\mathrm{L}$ & & Garlic & $9(0.08)$ & 1.11 & $\begin{array}{l}\text { Blood/ } \\
\text { Circulation }\end{array}$ & Decoction & Bi-weekly \\
\hline & & & & & & Joint pain & Leaves; decoction & Weekly \\
\hline & & & & & & Cuts & Ingested raw & As needed \\
\hline & & & & & & Hypertension & $\begin{array}{l}\text { Pods; grinded and } \\
\text { ingested with coconut } \\
\text { water }\end{array}$ & Daily \\
\hline & & & & & & $\begin{array}{l}\text { Immune } \\
\text { booster }\end{array}$ & Infusion & As needed \\
\hline & & & & & & Sores & Ingested raw & As needed \\
\hline \multirow[t]{11}{*}{ Annonaceae } & Annona muricata L & & Soursop & $21(0.18)$ & 1.14 & Cooling & $\begin{array}{l}\text { Leaves; decoction or } \\
\text { infusion }\end{array}$ & Daily, weekly \\
\hline & & & & & & $\begin{array}{l}\text { Health } \\
\text { maintenance }\end{array}$ & $\begin{array}{l}\text { Leaves; decoction or } \\
\text { infusion }\end{array}$ & Daily, weekly \\
\hline & & & & & & Hypertension & $\begin{array}{l}\text { Leaves; decoction or } \\
\text { infusion }\end{array}$ & Daily \\
\hline & & & & & & $\begin{array}{l}\text { Cancer } \\
\text { prevention }\end{array}$ & Leaves; decoction & - \\
\hline & & & & & & Constipation & Infusion & Daily \\
\hline & & & & & & Diabetes & Leaves (dried); decoction & Daily \\
\hline & & & & & & $\begin{array}{l}\text { Inflammatory } \\
\text { conditions }\end{array}$ & Leaves; decoction & Weekly \\
\hline & Annona squamosa L & DC012 & Sugar Apple & $4(0.03)$ & 1.25 & Cooling & Leaves; decoction & $\begin{array}{l}\text { Daily for } 1 \text { week } \\
\text { then } 2 \text {-weeks } \\
\text { break }\end{array}$ \\
\hline & & & & & & $\begin{array}{l}\text { Health } \\
\text { maintenance }\end{array}$ & Infusion & Daily \\
\hline & & & & & & Diabetes & Leaves (dried); decoction & Daily \\
\hline & & & & & & Hypertension & Leaves; decoction & Daily \\
\hline \multirow[t]{9}{*}{ Apiaceae } & Petroselinum crispum & & Parsley & $16(0.14)$ & 1.06 & Hypertension & decoction or infusion & Daily, weekly \\
\hline & (Mill.) Fuss & & & & & $\begin{array}{l}\text { Health } \\
\text { maintenance }\end{array}$ & Decoction & Weekly \\
\hline & & & & & & Cooling & infusion & Weekly \\
\hline & & & & & & Headache & Infusion & Monthly \\
\hline & & & & & & $\begin{array}{l}\text { Immune } \\
\text { booster }\end{array}$ & Infusion & As needed \\
\hline & Apium graveolens L & & Celery & $2(0.02)$ & 1.0 & Hypertension & Decoction or infusion & Daily \\
\hline & & & & & & $\begin{array}{l}\text { Health } \\
\text { maintenance }\end{array}$ & - & Weekly \\
\hline & Foeniculum vulgare Mill & & Fennel & $1(0.01)$ & 2.0 & Fever & Infusion & Daily \\
\hline & & & & & & Cough & Infusion or inhaled & - \\
\hline \multirow[t]{2}{*}{ Arecaceae } & Cocos nucifera L & & Coconut & $2(0.02)$ & 1.0 & Cooling & $\begin{array}{l}\text { Oil (+Epsom salts), applied } \\
\text { topically }\end{array}$ & Every 3 months \\
\hline & & & & & & Back pain & Oil, applied topically & Weekly \\
\hline \multirow[t]{9}{*}{ Asphodelaceae } & Aloe vera (L.) Burm.f & DC009 & Aloe & $17(0.15)$ & 1.24 & $\begin{array}{l}\text { Health } \\
\text { maintenance }\end{array}$ & $\begin{array}{l}\text { Gel; ingested raw, blended } \\
\text { with juice, decoction, or } \\
\text { infusion }\end{array}$ & Weekly, monthly \\
\hline & & & & & & Cleansing & Decoction or ingested raw & Weekly, monthly \\
\hline & & & & & & Cuts & $\begin{array}{l}\text { Leaf; cut open, applied } \\
\text { topically to wound }\end{array}$ & As needed \\
\hline & & & & & & Cold/Flu & Gel (blended); infusion & As needed \\
\hline & & & & & & Cough & Gel; ingested raw & As needed \\
\hline & & & & & & Diabetes & Ingested raw & Monthly \\
\hline & & & & & & $\begin{array}{l}\text { Immune } \\
\text { booster }\end{array}$ & Gel (blended); infusion & As needed \\
\hline & & & & & & Purgative & Ingested raw & Weekly \\
\hline & & & & & & Sores & $\begin{array}{l}\text { Leaf; cut open, applied } \\
\text { topically to sore }\end{array}$ & As needed \\
\hline
\end{tabular}

(Continued on following page) 
TABLE 3 | (Continued) List of medicinal plants, preparation methods and frequency of administration reported by users $(N=116)$.

\begin{tabular}{|c|c|c|c|c|c|c|c|c|}
\hline \multicolumn{4}{|l|}{ Plant } & \multirow{2}{*}{$\begin{array}{c}\text { FC } \\
\text { (RFC) }\end{array}$} & \multirow[t]{2}{*}{ UV } & \multicolumn{3}{|c|}{ Applications } \\
\hline Family & Species & $\begin{array}{l}\text { Voucher } \\
\text { No. }\end{array}$ & Local Name(s) & & & $\begin{array}{l}\text { Reported } \\
\text { Uses }\end{array}$ & $\begin{array}{l}\text { Preparation and } \\
\text { Administration }\end{array}$ & $\begin{array}{l}\text { Freq. of } \\
\text { Treatment }\end{array}$ \\
\hline \multirow[t]{8}{*}{ Asteraceae } & $\begin{array}{l}\text { Chromolaena odorata } \\
\text { (L.) R.M. King and }\end{array}$ & & Christmas Bush & $4(0.03)$ & 1.0 & $\begin{array}{l}\text { Health } \\
\text { maintenance }\end{array}$ & Decoction & Daily \\
\hline & H. Rob & & & & & Cooling & Infusion & Daily \\
\hline & & & & & & Fever & $\begin{array}{l}\text { Decoction (+Pambaram } \\
\text { and Cerasee) }\end{array}$ & As needed \\
\hline & Parthenium & & Whitehead Bush & $2(0.02)$ & 1.0 & Joint pain & Twigs; infusion & As needed \\
\hline & hysterophorus L & & & & & Eczema & $\begin{array}{l}\text { Soaked in water and left on } \\
\text { skin until dry }\end{array}$ & As needed \\
\hline & $\begin{array}{l}\text { Pluchea carolinensis } \\
\text { (Jacq.) G. Don }\end{array}$ & & Cure-for-All & $1(0.01)$ & 1.0 & Cold/Flu & Infusion & As needed \\
\hline & Lactuca virosa Habl & & Wild Lettuce & $1(0.01)$ & 2.0 & Joint/Back pain & Infusion & Weekly \\
\hline & Bidens pilosa L & & $\begin{array}{l}\text { Duppy needles/ } \\
\text { Monkey Needles/ } \\
\text { Spanish Needles }\end{array}$ & $1(0.01)$ & 1.0 & Hypertension & Decoction & - \\
\hline \multirow[t]{3}{*}{ Boraginaceae } & Cordia obliqua Willd & DC006 & Clammy Cherry & $1(0.01)$ & 1.0 & Cooling & Leaves; decoction & Daily \\
\hline & Borago officinalis L & & Starflower & $1(0.01)$ & 1.0 & $\begin{array}{l}\text { Hormonal } \\
\text { balance }\end{array}$ & Capsule; ingested orally & Daily \\
\hline & Symphytum officinale L & & Comfrey & $1(0.01)$ & 1.0 & $\begin{array}{l}\text { Health } \\
\text { maintenance }\end{array}$ & Decoction or infusion & Daily \\
\hline Cannabaceae & Cannabis sativus L & & Marijuana & $1(0.01)$ & 1.0 & Vomiting & Leaves; decoction & - \\
\hline \multirow[t]{3}{*}{ Caricaceae } & Carica papaya L & DC011 & Pawpaw & $11(0.1)$ & 1.27 & Hypertension & $\begin{array}{l}\text { Decoction, infusion, or } \\
\text { ingested raw }\end{array}$ & $\begin{array}{l}\text { Daily, monthly, } \\
\text { as needed }\end{array}$ \\
\hline & & & & & & Constipation & Infusion or eaten raw & Daily, as needed \\
\hline & & & & & & Cold/Flu & Leaves; decoction & As needed \\
\hline Clusiaceae & Clusia plukenetii Urb & & Rock Balsam & $1(0.01)$ & 1.0 & Cough & Leaves; chewed & As needed \\
\hline \multirow[t]{6}{*}{ Crassulaceae } & $\begin{array}{l}\text { Kalanchoe pinnata } \\
\text { (Lam.) Pers }\end{array}$ & DC005 & Wonder of the World & $11(0.1)$ & 1.09 & Cough & $\begin{array}{l}\text { Leaves; decoction or } \\
\text { ingested raw }\end{array}$ & As needed \\
\hline & & & & & & Cold/Flu & Dried, decoction & As needed \\
\hline & & & & & & Cleansing & Decoction or infusion & Annually \\
\hline & & & & & & Headache & Infusion & As needed \\
\hline & & & & & & $\begin{array}{l}\text { Health } \\
\text { maintenance }\end{array}$ & Decoction or infusion & Daily \\
\hline & & & & & & Sores & Applied topically to wound & As needed \\
\hline \multirow[t]{15}{*}{ Cucurbitaceae } & Momordica charantia L & DC002 & Cerasee & $28(0.24)$ & 1.32 & $\begin{array}{l}\text { Health } \\
\text { maintenance }\end{array}$ & $\begin{array}{l}\text { Dried, decoction or } \\
\text { infusion }\end{array}$ & Weekly, monthly \\
\hline & & & & & & Cold/Flu & Decoction & As needed \\
\hline & & & & & & Cleansing & Decoction or infusion & Monthly \\
\hline & & & & & & Cough & Decoction or infusion & As needed \\
\hline & & & & & & Fever & $\begin{array}{l}\text { Leaves; decoction or } \\
\text { chewed }\end{array}$ & As needed \\
\hline & & & & & & Hypertension & Infusion & Weekly, monthly \\
\hline & & & & & & Diabetes & Decoction & $\begin{array}{l}\text { As needed, } \\
\text { monthly }\end{array}$ \\
\hline & & & & & & $\begin{array}{l}\text { Cancer } \\
\text { prevention }\end{array}$ & Leaves; decoction & - \\
\hline & & & & & & Constipation & Leaves; infusion & Daily \\
\hline & & & & & & Cooling & Infusion & - \\
\hline & & & & & & Headache & Infusion & As needed \\
\hline & & & & & & Upset stomach & Decoction & As needed \\
\hline & Cucumis sativus L & & Cucumber & $3(0.03)$ & 1.0 & Sore eye & Placed on eyelids & As needed \\
\hline & & & & & & Hypertension & Infusion (+parsley) & Daily \\
\hline & $\begin{array}{l}\text { Citrullus lanatus } \\
\text { (Thumb) Matsum. and } \\
\text { Nakai }\end{array}$ & & Melon & $1(0.01)$ & 1.0 & Cooling & $\begin{array}{l}\text { Rinds; soaked in water and } \\
\text { drunk }\end{array}$ & Daily \\
\hline Dilleniaceae & $\begin{array}{l}\text { Doliocarpus dentatus } \\
\text { (Aubl.) Standl }\end{array}$ & & Capadulla & $1(0.01)$ & 1.0 & Back pain & Bark; decoction & As needed \\
\hline Ericaceae & Vaccinium myrtillus $L$ & & Bilberry & $1(0.01)$ & 1.0 & Sore eye & Leaves; infusion & As needed \\
\hline
\end{tabular}

(Continued on following page) 
TABLE 3 | (Continued) List of medicinal plants, preparation methods and frequency of administration reported by users $(N=116)$.

\begin{tabular}{|c|c|c|c|c|c|c|c|c|}
\hline \multicolumn{4}{|l|}{ Plant } & \multirow{2}{*}{$\begin{array}{c}\text { FC } \\
\text { (RFC) }\end{array}$} & \multirow[t]{2}{*}{ UV } & \multicolumn{3}{|c|}{ Applications } \\
\hline Family & Species & $\begin{array}{l}\text { Voucher } \\
\text { No. }\end{array}$ & Local Name(s) & & & $\begin{array}{l}\text { Reported } \\
\text { Uses }\end{array}$ & $\begin{array}{l}\text { Preparation and } \\
\text { Administration }\end{array}$ & $\begin{array}{c}\text { Freq. of } \\
\text { Treatment }\end{array}$ \\
\hline \multirow[t]{6}{*}{ Euphorbiaceae } & Ricinus communis L & DC004 & Castor Bean, Castor & $2(0.02)$ & 1.5 & Sore eye & Oil; applied topically to eye & As needed \\
\hline & & & Oil Plant & & & Constipation & Oil; ingested orally & As needed \\
\hline & & & & & & Upset stomach & - & - \\
\hline & Croton malabaricus & & Pambaram & $2(0.02)$ & 1.5 & Cooling & decoction & Bi-weekly \\
\hline & Bedd & & & & & $\begin{array}{l}\text { Health } \\
\text { maintenance }\end{array}$ & decoction & Daily \\
\hline & & & & & & Fever & $\begin{array}{l}\text { Decoction (+Christmas } \\
\text { Bush and Cerasee) }\end{array}$ & Daily \\
\hline \multirow[t]{5}{*}{ Fabaceae } & $\begin{array}{l}\text { Caesalpinia } \\
\text { pulcherrima (L.) Sw }\end{array}$ & DC014 & $\begin{array}{l}\text { Pride of Barbados, } \\
\text { Flower Fence }\end{array}$ & $3(0.03)$ & 0.67 & Cooling & Leaves; decoction & - \\
\hline & Abrus precatorius $\mathrm{L}$ & & Crab Eye & $2(0.02)$ & 1.0 & $\begin{array}{l}\text { Health } \\
\text { maintenance }\end{array}$ & decoction & Daily \\
\hline & & & & & & Cough & infusion & As needed \\
\hline & $\begin{array}{l}\text { Senna bicapsularis (L.) } \\
\text { Roxb }\end{array}$ & & $\begin{array}{l}\text { Senna, Money Bush, } \\
\text { Monkey Tamarind }\end{array}$ & $1(0.01)$ & 1.0 & Cleansing & Decoction or infusion & Annually \\
\hline & $\begin{array}{l}\text { Trigonella foenum- } \\
\text { graecum } \mathrm{L}\end{array}$ & & Fenugreek & $1(0.01)$ & 1.0 & Joint pain & Infusion & Weekly \\
\hline \multirow[t]{10}{*}{ Lamiaceae } & Mentha $\times$ piperita L./ & & Peppermint, Mint & $9(0.08)$ & 1.0 & Cooling & Infusion & Daily, weekly \\
\hline & Mentha sp & & & & & Fever & Leaves; decoction & As needed \\
\hline & & & & & & Cold/Flu & Infusion & As needed \\
\hline & & & & & & Hypertension & Infusion & Daily \\
\hline & & & & & & $\begin{array}{l}\text { Health } \\
\text { maintenance }\end{array}$ & Infusion & Weekly \\
\hline & Ocimum basilicum L & & Basil & $3(0.03)$ & 1.0 & Cooling & Infusion & Daily, as needed \\
\hline & Thymus vulgaris $\mathrm{L}$ & & Thyme & $3(0.03)$ & 0.67 & Headache & Infusion & Daily \\
\hline & & & & & & $\begin{array}{l}\text { Health } \\
\text { maintenance }\end{array}$ & Infusion & Daily \\
\hline & Rosmarinus officinalis $\mathrm{L}$ & & Rosemary & $1(0.01)$ & 1.0 & Cooling & Decoction (+Moringa) & Daily \\
\hline & Marrubium vulgare $\mathrm{L}$ & & Horehound & $1(0.01)$ & 1.0 & Cough & Infusion & As needed \\
\hline \multirow[t]{7}{*}{ Lauraceae } & Persea americana Mill & & Pear & $16(0.14)$ & 1.13 & Cooling & Leaf; decoction or infusion & Daily, weekly \\
\hline & & & & & & Hypertension & Leaf; decoction or infusion & Daily \\
\hline & & & & & & $\begin{array}{l}\text { Health } \\
\text { maintenance }\end{array}$ & Leaf; infusion & $\begin{array}{l}\text { Weekly or } \\
\text { monthly }\end{array}$ \\
\hline & & & & & & Cold/Flu & Leaf; decoction & As needed \\
\hline & & & & & & Diarrhea & Leaf; infusion & Once per week \\
\hline & & & & & & Headache & Leaf; infusion & Monthly \\
\hline & & & & & & Purgative & Leaf; decoction & Weekly \\
\hline Linaceae & Linum usitatissimum L & & Flax, Linseed & $1(0.01)$ & 1.0 & Joint pain & Ingested in powder form & Daily \\
\hline \multirow[t]{2}{*}{ Lythraceae } & Punica granatum L & DC013 & Pomegranate & $2(0.02)$ & 1.0 & Cooling & Decoction & - \\
\hline & & & & & & $\begin{array}{l}\text { Health } \\
\text { maintenance }\end{array}$ & Infusion & Monthly \\
\hline Malvaceae & $\begin{array}{l}\text { Hibiscus rosa- } \\
\text { sinensis } L\end{array}$ & DC015 & Hibiscus Flower & $2(0.02)$ & 1.0 & $\begin{array}{l}\text { Health } \\
\text { maintenance }\end{array}$ & - & - \\
\hline \multirow[t]{10}{*}{ Meliaceae } & $\begin{array}{l}\text { Azadirachta indica A. } \\
\text { Juss }\end{array}$ & & Neem & $13(0.11)$ & 1.54 & Diabetes & Leaf; decoction & $\begin{array}{l}\text { Weekly or } \\
\text { monthly }\end{array}$ \\
\hline & & & & & & Hypertension & Leaf; decoction & Monthly \\
\hline & & & & & & $\begin{array}{l}\text { Health } \\
\text { maintenance }\end{array}$ & Decoction & $\begin{array}{l}\text { Weekly or } \\
\text { monthly }\end{array}$ \\
\hline & & & & & & Cleansing & Leaf; infusion & Weekly \\
\hline & & & & & & Cooling & Leaf; infusion & $\begin{array}{l}\text { Daily for } 1 \text { week } \\
\text { then } 2 \text {-weeks } \\
\text { break }\end{array}$ \\
\hline & & & & & & Joint/Back pain & Decoction & Weekly \\
\hline & & & & & & Cough & Decoction & As needed \\
\hline & & & & & & Cuts & $\begin{array}{l}\text { Pods; applied topically to } \\
\text { wound }\end{array}$ & As needed \\
\hline & & & & & & $\begin{array}{l}\text { Immune } \\
\text { booster }\end{array}$ & Blended, infusion & As needed \\
\hline & & & & & & Sore eye & Leaf; decoction & As needed \\
\hline
\end{tabular}

\footnotetext{
(Continued on following page)
} 
TABLE 3 | (Continued) List of medicinal plants, preparation methods and frequency of administration reported by users $(N=116)$.

\begin{tabular}{|c|c|c|c|c|c|c|c|c|}
\hline \multicolumn{4}{|l|}{ Plant } & \multirow{2}{*}{$\begin{array}{c}\text { FC } \\
\text { (RFC) }\end{array}$} & \multirow[t]{2}{*}{ UV } & \multicolumn{3}{|c|}{ Applications } \\
\hline Family & Species & $\begin{array}{l}\text { Voucher } \\
\text { No. }\end{array}$ & Local Name(s) & & & $\begin{array}{l}\text { Reported } \\
\text { Uses }\end{array}$ & $\begin{array}{l}\text { Preparation and } \\
\text { Administration }\end{array}$ & $\begin{array}{c}\text { Freq. of } \\
\text { Treatment }\end{array}$ \\
\hline \multirow[t]{2}{*}{ Moraceae } & $\begin{array}{l}\text { Artocarpus altilis } \\
\text { (Parkinson) Fosberg }\end{array}$ & & Breadfruit & $3(0.03)$ & 1.0 & $\begin{array}{l}\text { Health } \\
\text { maintenance }\end{array}$ & Infusion & Weekly \\
\hline & & & & & & Hypertension & Leaf; infusion & Weekly \\
\hline \multirow[t]{7}{*}{ Moringaceae } & Moringa oleifera Lam & & Moringa & $18(0.16)$ & 1.06 & $\begin{array}{l}\text { Health } \\
\text { maintenance }\end{array}$ & $\begin{array}{l}\text { Leaf; decoction } \\
\text { Nuts; ingested raw }\end{array}$ & Daily, weekly \\
\hline & & & & & & Diabetes & Decoction or infusion & Weekly \\
\hline & & & & & & Hypertension & Decoction & Weekly \\
\hline & & & & & & Cleansing & $\begin{array}{l}\text { Decoction (+sugar) or } \\
\text { infusion }\end{array}$ & Weekly, monthly \\
\hline & & & & & & Cooling & Decoction & Daily \\
\hline & & & & & & Cough & Seeds; chewed & As needed \\
\hline & & & & & & $\begin{array}{l}\text { Immune } \\
\text { booster }\end{array}$ & Blended, infusion & As needed \\
\hline \multirow[t]{3}{*}{ Musaceae } & Musa acuminata Colla & DC007 & Banana & $2(0.02)$ & 1.0 & Iron & - & - \\
\hline & & & & & & supplement & & \\
\hline & & & & & & Toothache & Stub; decoction & As needed \\
\hline \multirow[t]{2}{*}{ Myristicaceae } & Myristica fragrans & & Nutmeg & $2(0.02)$ & 1.0 & Upset stomach & Grated, infusion & As needed \\
\hline & Houtt & & & & & Headache & $\begin{array}{l}\text { Mixed with candle grease, } \\
\text { applied to cloth, and } \\
\text { placed on head }\end{array}$ & As needed \\
\hline \multirow[t]{11}{*}{ Myrtaceae } & Syzygium aromaticum & & Clove & $2(0.02)$ & 1.0 & Toothache & Cloves; decoction & As needed \\
\hline & $\begin{array}{l}\text { (L.) Merr. and L.M. } \\
\text { Perry }\end{array}$ & & & & & $\begin{array}{l}\text { Health } \\
\text { maintenance }\end{array}$ & - & - \\
\hline & $\begin{array}{l}\text { Pimenta racemosa } \\
\text { (Mill.) J.W. Moore }\end{array}$ & DC018 & Bay Leaf & $30(0.26)$ & 1.17 & Cooling & $\begin{array}{l}\text { Leaves; decoction } \\
\text { (+sugar) or infusion }\end{array}$ & Daily, weekly \\
\hline & & & & & & $\begin{array}{l}\text { Health } \\
\text { maintenance }\end{array}$ & Decoction or infusion & Daily, weekly \\
\hline & & & & & & Hypertension & Decoction or infusion & Daily \\
\hline & & & & & & Cleansing & Decoction (+sugar) & Monthly \\
\hline & & & & & & Cold/Flu & Decoction & As needed \\
\hline & & & & & & Headache & Infusion & As needed \\
\hline & & & & & & Sinus issues & Decoction & As needed \\
\hline & & & & & & Upset stomach & Infusion & Monthly \\
\hline & Psidium guajava L & & Guava & $1(0.01)$ & 1.0 & Sore throat & Ingested orally & As needed \\
\hline Oleaceae & Syringa vulgaris L & & Lilac & $1(0.01)$ & 1.0 & - & - & - \\
\hline Onagraceae & Oenothera biennis L & & Evening Primrose & $1(0.01)$ & 1.0 & $\begin{array}{l}\text { Hormonal } \\
\text { balance }\end{array}$ & Capsule, ingested orally & Daily \\
\hline Papaveracae & Argemome mexicana $\mathrm{L}$ & & Holly Hock & $1(0.01)$ & 1.0 & Nosebleed & - & - \\
\hline Phytolaccaceae & Petiveria alliacea $\mathrm{L}$ & & Gully Root & $1(0.01)$ & 1.0 & Cough & $\begin{array}{l}\text { Decoction (+sugar and } \\
\text { salt) }\end{array}$ & As needed \\
\hline \multirow[t]{8}{*}{ Poaceae } & Cymbopogon citratus & DC001 & Lemongrass, Fever & $18(0.16)$ & 1.11 & Cough & Decoction & As needed \\
\hline & (DC.) Stapf & & Grass & & & Cooling & Decoction & Daily \\
\hline & & & & & & $\begin{array}{l}\text { Health } \\
\text { maintenance }\end{array}$ & Decoction or infusion & Daily, monthly \\
\hline & & & & & & Cold/Flu & - & - \\
\hline & & & & & & Fever & Decoction & As needed \\
\hline & & & & & & $\begin{array}{l}\text { Inflammatory } \\
\text { conditions }\end{array}$ & - & - \\
\hline & & & & & & Joint pain & Infusion & Weekly \\
\hline & & & & & & Sinus issues & - & - \\
\hline \multirow[t]{2}{*}{ Ranunculaceae } & Hydrastis canadensis $\mathrm{L}$ & & Goldenseal & $1(0.01)$ & 1.0 & $\begin{array}{l}\text { Health } \\
\text { maintenance }\end{array}$ & - & - \\
\hline & Nigella sativa L & & $\begin{array}{l}\text { Blackseed, Black } \\
\text { Cumin }\end{array}$ & $1(0.01)$ & 1.0 & Hypertension & Oil extract & - \\
\hline \multirow[t]{4}{*}{ Rubiaceae } & Morinda citrifolia L & & Noni, Dog Dumpling & $2(0.02)$ & 1.0 & Joint pain & Leaf, fruit; decoction & As needed \\
\hline & & & & & & $\begin{array}{l}\text { Health } \\
\text { maintenance }\end{array}$ & Blended with juice & Monthly \\
\hline & $\begin{array}{l}\text { Psychotria } \\
\text { tenuifolia Sw }\end{array}$ & & Coffee Bush & $2(0.02)$ & 1.0 & $\begin{array}{l}\text { Health } \\
\text { maintenance }\end{array}$ & decoction & Daily \\
\hline & & & & & & Diabetes & Dried, decoction & Daily \\
\hline
\end{tabular}


TABLE 3 | (Continued) List of medicinal plants, preparation methods and frequency of administration reported by users $(N=116)$.

\begin{tabular}{|c|c|c|c|c|c|c|c|c|}
\hline \multicolumn{4}{|l|}{ Plant } & \multirow{2}{*}{$\begin{array}{c}\text { FC } \\
\text { (RFC) }\end{array}$} & \multirow[t]{2}{*}{ UV } & \multicolumn{3}{|c|}{ Applications } \\
\hline Family & Species & $\begin{array}{l}\text { Voucher } \\
\text { No. }\end{array}$ & Local Name(s) & & & $\begin{array}{l}\text { Reported } \\
\text { Uses }\end{array}$ & $\begin{array}{l}\text { Preparation and } \\
\text { Administration }\end{array}$ & $\begin{array}{l}\text { Freq. of } \\
\text { Treatment }\end{array}$ \\
\hline \multirow[t]{5}{*}{ Rutaceae } & $\begin{array}{l}\text { Citrus limon (L.) } \\
\text { Osbeck }\end{array}$ & & Lemon & $4(0.03)$ & 0.75 & $\begin{array}{l}\text { Health } \\
\text { maintenance }\end{array}$ & Decoction & Daily \\
\hline & & & & & & Cooling & Infusion & - \\
\hline & & & & & & Diabetes & Infusion & As needed \\
\hline & Dictamnus albus L & & Moses Papa Bush & $1(0.01)$ & 1.0 & Cough & - & - \\
\hline & $\begin{array}{l}\text { Citrus sinensis (L.) } \\
\text { Osbeck }\end{array}$ & & Orange & $1(0.01)$ & 1.0 & $\begin{array}{l}\text { Immune } \\
\text { booster }\end{array}$ & $\begin{array}{l}\text { Blended, infusion Capsule } \\
\text { ingested orally }\end{array}$ & As needed \\
\hline Salvadoraceae & Salvadora persica L & & Mustard Bush & $1(0.01)$ & 1.0 & Nosebleed & - & - \\
\hline \multirow[t]{2}{*}{ Scrophulariaceae } & Bontia daphnoides L & & Wild Olive & $2(0.02)$ & 1.0 & $\begin{array}{l}\text { Health } \\
\text { maintenance }\end{array}$ & Infusion & Daily \\
\hline & & & & & & Cooling & Decoction & Daily \\
\hline \multirow[t]{3}{*}{ Solanaceae } & Solanum tuberosum L & & English Potato & $1(0.01)$ & 1.0 & Sore eye & $\begin{array}{l}\text { Soak in water, mix with } \\
\text { castor oil and use to } \\
\text { wash eye }\end{array}$ & As needed \\
\hline & Capsicum annum L & & Cayenne pepper & $1(0.01)$ & 1.0 & Sinus issues & - & - \\
\hline & & & & & & Diverticulitis & - & - \\
\hline \multirow[t]{8}{*}{ Verbenaceae } & Lantana camara L & DC019 & Sage & $1(0.01)$ & 0.5 & Cooling & Infusion & Daily \\
\hline & & & & & & Diabetes & Infusion & Daily \\
\hline & Stachytarpheta & DC003 & Vervain & $5(0.04)$ & 1.4 & Cold/Flu & Ingested orally & As needed \\
\hline & jamaicensis (L.) Vahl & & & & & Cough & Infusion & Weekly \\
\hline & & & & & & Hypertension & Decoction or infusion & Weekly \\
\hline & & & & & & Joint pain & Infusion & - \\
\hline & & & & & & Headache & Infusion & Monthly \\
\hline & & & & & & $\begin{array}{l}\text { Health } \\
\text { maintenance }\end{array}$ & Infusion & Monthly \\
\hline \multirow[t]{16}{*}{ Zingiberaceae } & $\begin{array}{l}\text { Zingiber officinale } \\
\text { Roscoe }\end{array}$ & & Ginger & $22(0.19)$ & 1.14 & $\begin{array}{l}\text { Health } \\
\text { maintenance }\end{array}$ & $\begin{array}{l}\text { Rhizome (grated or whole); } \\
\text { decoction or infusion }\end{array}$ & $\begin{array}{l}\text { Daily, weekly, } \\
\text { monthly }\end{array}$ \\
\hline & & & & & & Joint/Back pain & $\begin{array}{l}\text { Rhizome; decoction, } \\
\text { infusion, or cooked in stew }\end{array}$ & Daily, weekly \\
\hline & & & & & & $\begin{array}{l}\text { Blood/ } \\
\text { Circulation }\end{array}$ & Rhizome; decoction & Bi-weekly \\
\hline & & & & & & Hypertension & Rhizome; decoction & Weekly \\
\hline & & & & & & Upset stomach & $\begin{array}{l}\text { Rhizome; decoction or } \\
\text { infusion }\end{array}$ & As needed \\
\hline & & & & & & Cooling & Infusion & Daily \\
\hline & & & & & & Diarrhea & Rhizome; decoction & As needed \\
\hline & & & & & & Dyspnea & Infusion & Daily \\
\hline & & & & & & $\begin{array}{l}\text { Immune } \\
\text { booster }\end{array}$ & Blended, infusion & As needed \\
\hline & & & & & & $\begin{array}{l}\text { Inflammatory } \\
\text { conditions }\end{array}$ & - & - \\
\hline & & & & & & Sinus issues & - & - \\
\hline & Curcuma longa L & & Turmeric & $11(0.1)$ & 1.27 & $\begin{array}{l}\text { Health } \\
\text { maintenance }\end{array}$ & $\begin{array}{l}\text { Decoction, infusion or } \\
\text { tablet ingested orally }\end{array}$ & $\begin{array}{l}\text { Daily, weekly, } \\
\text { monthly }\end{array}$ \\
\hline & & & & & & Hypertension & Decoction or infusion & Daily, weekly \\
\hline & & & & & & Joint/Back pain & $\begin{array}{l}\text { Decoction, infusion, or } \\
\text { cooked in stew }\end{array}$ & Daily, weekly \\
\hline & & & & & & $\begin{array}{l}\text { Blood/ } \\
\text { Circulation }\end{array}$ & Decoction & Bi-weekly \\
\hline & & & & & & $\begin{array}{l}\text { Inflammatory } \\
\text { conditions }\end{array}$ & Decoction & As needed \\
\hline
\end{tabular}

reports for some of the most reported species in both studies, including $M$. charantia, which our study identified as useful for cancer prevention, constipation, cooling, headache, and upset stomach, as well as C. papaya (Pawpaw), which was identified as useful in both colds/flu and constipation. Notably, there were no similarities in the use reports for Stachytarpheta jamaicensis (L.) Vahl (Vervain) identified by Peter (2013)-which were few and mainly neurological - and those identified in this study, which were more diverse and included cough, colds/flu, hypertension, joint pain, and health maintenance. This finding is noteworthy considering the much smaller and more focused rural setting of this study compared to that done by Peter, which surveyed 11 parishes across Barbados. In particular, this may provide support for the notion that traditional plant knowledge is retained and preserved to a greater extent in rural communities than in more urban localities. 


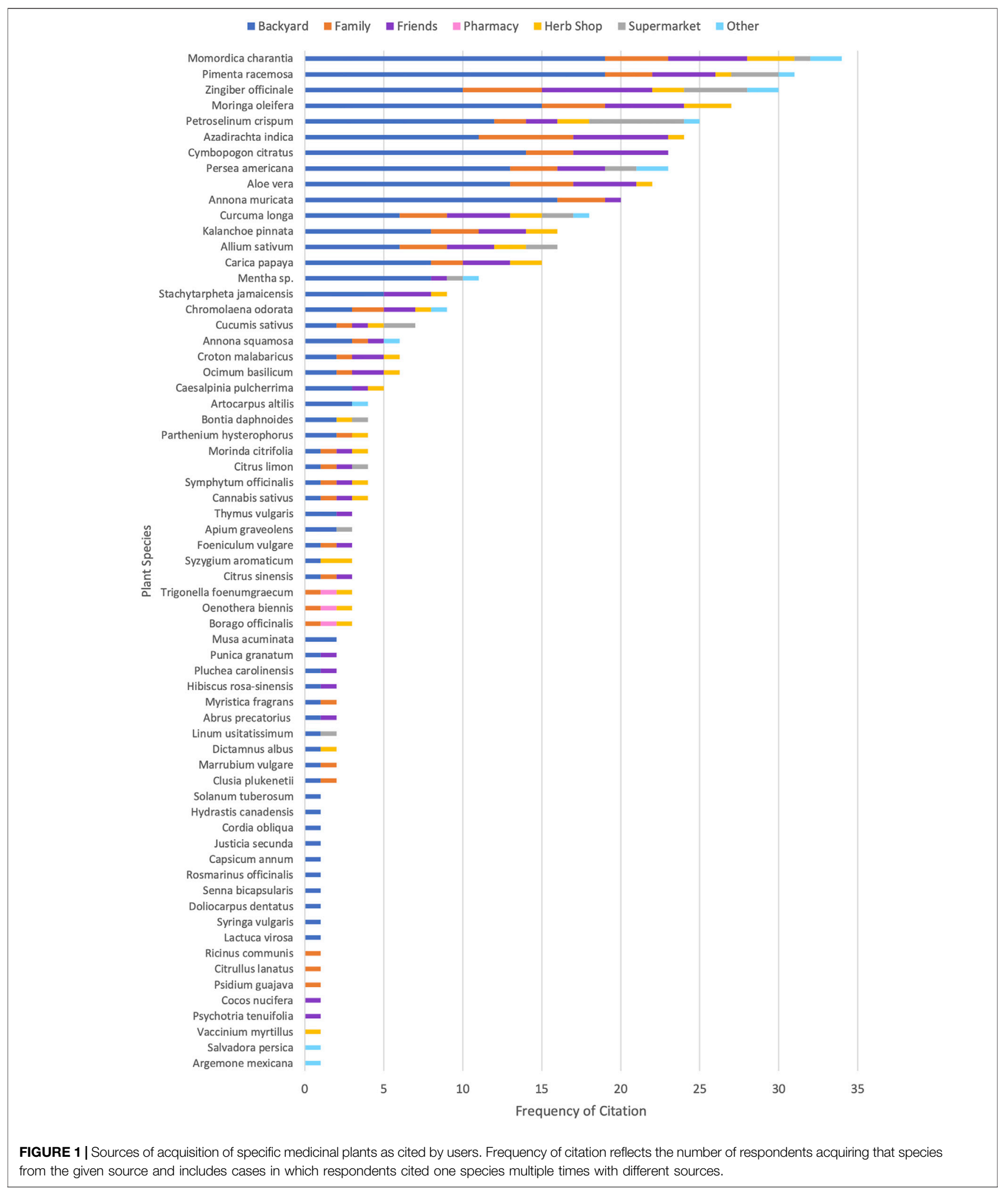

Hypertension, cough, and influenza proved to be the top three medical illnesses that participants in our study treated with botanical medicines, which is not surprising considering hypertension, heart disease and lower respiratory infections are among the top ten causes of morbidity and mortality in Barbados (Global Burden of Disease Collaborative Network, 
TABLE 4 | Contingency Table and Fisher's Exact Test Results for Knowledge Acquired from Family x Medicinal Plants Sourced from Family ( $\mathrm{n}=108$ ).

Medicinal

Plants from Family

Yes

No

Column Total (\%)

\begin{tabular}{cc}
\multicolumn{2}{c}{ Knowledge from Family } \\
\hline Yes & No \\
$20(22.5)^{\mathrm{a}}$ & $0(0.0)^{\mathrm{a}}$ \\
$69(77.5)^{\mathrm{a}}$ & $19(100.0)^{\mathrm{a}}$ \\
$89(100.0)$ & $19(100.0)$
\end{tabular}

Row Total (\%)

\begin{tabular}{cc} 
& $\boldsymbol{p}$-value (ES) \\
$20(18.5)$ & \\
$88(81.5)$ & $0.02(0.22)$ \\
\hline
\end{tabular}

${ }^{a}$ Percent within Knowledge from Family (column \%).

Note: $E S=$ effect size.

TABLE 5 | Contingency Table and Chi-Squared Results for Knowledge Acquired from Friends $\times$ Medicinal Plants Sourced from Friends $(n=108$, df = 1).

\begin{tabular}{|c|c|c|c|c|}
\hline \multirow{2}{*}{$\begin{array}{l}\text { Medicinal } \\
\text { Plants from Friends }\end{array}$} & \multicolumn{2}{|c|}{ Knowledge from Friends } & \multirow[t]{2}{*}{ Row Total (\%) } & \multirow[t]{2}{*}{$\chi^{2}, p$-value (ES) } \\
\hline & Yes & No & & \\
\hline Yes & $15(41.7)^{a}$ & $13(18.1)^{\mathrm{a}}$ & $28(25.9)$ & \\
\hline No & $21(58.3)^{a}$ & $59(81.9)^{a}$ & $80(74.1)$ & $6.967,0.008(0.25)$ \\
\hline Column Total (\%) & $36(100.0)$ & $72(100.0)$ & $108(100.0)$ & \\
\hline
\end{tabular}

${ }^{a}$ Percent within Knowledge from Friends (column \%).

Note: $E S=$ effect size.

TABLE 6 | Contingency Table and Fisher's Exact Test Results for Education Level x Medicinal Plants Sourced from Backyard $(n=107)$.

Level of Education

Primary or less
Secondary
Associate/Nocational
Undergraduate +

Column Total (\%)

\begin{tabular}{cc}
\multicolumn{3}{c}{ Medicinal Plants from Backyard } \\
\hline Yes
\end{tabular}

$\begin{array}{cc}34(89.5)^{\mathrm{a}} & 4(10.5)^{\mathrm{a}} \\ 29(61.7)^{\mathrm{a}} & 18(38.3)^{\mathrm{a}} \\ 9(69.2)^{\mathrm{a}} & 4(30.8)^{\mathrm{a}} \\ 6(66.7)^{\mathrm{a}} & 3(33.3)^{\mathrm{a}} \\ 78(72.9) & 29(27.1)\end{array}$

Row Total (\%)

$38(100.0)$

$46(100.0)$

$13(100.0)$

9 (100.0)

107 (100.0) p-value (ES)

$0.02(0.28)$

${ }^{a}$ Percent within Level of Education (row \%).

Note: $E S=$ effect size.

TABLE 7 | Contingency Table and Chi-Squared Results for Annual Income $\times$ Medicinal Plants Sourced from Family $(\mathrm{n}=90$, df = 1).

\begin{tabular}{|c|c|c|c|c|}
\hline \multirow[t]{2}{*}{ Annual Income } & \multicolumn{2}{|c|}{ Botanical Medicines from Family } & \multirow[t]{2}{*}{ Row Total (\%) } & \multirow[t]{2}{*}{$\chi^{2}, p$-value (ES) } \\
\hline & Yes & No & & \\
\hline Less than $\$ 18,000$ & $6(10.7)^{\mathrm{a}}$ & $50(89.3)^{a}$ & $56(100.0)$ & \\
\hline More than $\$ 18,000$ & $10(29.4)^{\mathrm{a}}$ & $24(70.6)^{a}$ & $34(100.0)$ & $5.060,0.02(0.24)$ \\
\hline Column Total (\%) & $16(17.8)$ & $74(82.2)$ & $90(100.0)$ & \\
\hline
\end{tabular}

${ }^{a}$ Percent within Annual Income (row \%).

Note: $E S=$ effect size.

2020). Our study also showed that $62.1 \%$ of medicinal plant users suffered from at least one chronic non-communicable condition, with hypertension being the most prevalent. This is not alarming considering the median age group was 51-60 years, a popular age group for the onset of degenerative chronic diseases as well as a high prevalence of chronic conditions in Barbados (Unwin et al., 2015; Prasad et al., 2012). In fact, the 2015 Health of the Nation Survey found that roughly $45 \%$ of Barbadian adults are hypertensive, $25 \%$ have diabetes, and $21 \%$ are hypercholesterolemic; additionally, these figures were shown to increase with age (Unwin et al., 2015). Interestingly, botanical medicines were most frequently used for "health maintenance", cleansing (i.e., detoxifying), and cooling (i.e., eliminating heat or irritable behaviour), which are folkloric practices. It is likely that these practices persist in present-day Barbados as relics of the historical beliefs concerning health and disease that underpinned the traditions held by the enslaved West Africans and European colonialists. For example, two pillars of West African health and healing traditions include spiritual cleansing, as well as achieving and maintaining stability among the physical, mental, spiritual, and emotional domains - both of which involve the use of medicinal plants (White, 2015). The use of "cleansing" remedies in Caribbean society today echoes this spiritual cleansing practiced by slaves, although it has gradually become 
TABLE 8 | Contingency Table and Chi-Squared Results for Parental Use of Botanical Medicines $(n=88, \mathrm{df}=1)$ and Chronic Condition $(n=103$, df $=1) \times$ Concomitant Use of Conventional and Botanical Medicines.

\begin{tabular}{lccc}
\hline & \multicolumn{2}{c}{$\begin{array}{c}\text { Concomitant Use of Botanical and } \\
\text { Conventional Medicines }\end{array}$} & Row Total (\%) \\
\cline { 2 - 3 } & Yes & No & \\
\hline Parental Herb Use & & & \\
Yes & $11(20.0)^{\mathrm{a}}$ & $44(80.0)^{\mathrm{a}}$ & $55(100.0)$ \\
No & $13(39.4)^{\mathrm{a}}$ & $20(60.6)^{\mathrm{a}}$ & $33(100.0)$ \\
Column Total (\%) & $24(27.3)$ & $64(72.7)$ & $88(100.0)$ \\
Chronic Condition & & & $69(100.0)$ \\
Yes & $28(40.6)^{\mathrm{b}}$ & $41(59.4)^{\mathrm{b}}$ & $34(100.0)$ \\
No & $4(11.8)^{\mathrm{b}}$ & $30(88.2)^{\mathrm{b}}$ & $103(100.0)$ \\
Column Total (\%) & $32(31.1)$ & $71(68.9)$ & \\
\hline
\end{tabular}

${ }^{a}$ Percent within Parental Use of Botanical Medicines (row \%).

${ }^{b}$ Percent within Chronic Condition (row \%).

Note: $E S=$ effect size.

TABLE 9 | Contingency Tables and Fisher's Exact Test/Chi-Squared Results for Level of Education $(n=152, \mathrm{df}=3)$ and Health Insurance $(n=152$, df $=1) \times$ Botanical Medicine Use.

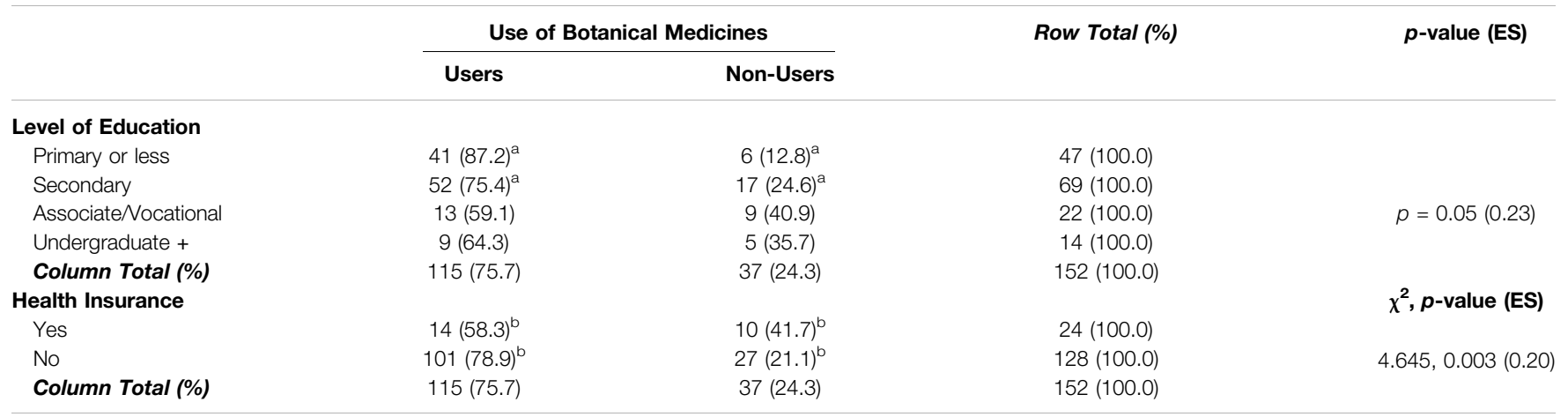

${ }^{a}$ Percent within Level of Education (row \%).

${ }^{b}$ Percent within Health Insurance (row \%).

Note: $E S=$ effect size.

more focused on physical rather than extra-physical healing (Clement et al., 2015; White, 2015). Similarly, the botanical medicines used for "health maintenance" today are likely to reflect those used by West African slaves to achieve stability among the physical, mental, and spiritual domains. The use of cooling remedies, however, mirrors the European humoral theory of health and disease in which diseases were classified as hot or cold - the former being treated with cooling remedies and vice versa (Cook and Walker, 2013).

Other ethnobotanical studies conducted in the Caribbean basin have also documented the use of medicinal plants for cleansing and cooling (Clement et al., 2015; Picking et al., 2015; Tareau et al., 2017), supporting the notion that these medico-cultural concepts represent a lasting impact of the cultural diversity that began in the Caribbean during the colonial era. However, the most compelling support of this finding is provided by Handler and Jacoby (1993) in their examination of slave medicine and plant use, in which the medicinal plants used by slaves prior to 1834 are documented. The list cites several plants that are still used in Barbados today (as identified by this study and Peter (2013)), as well as the medicocultural uses of these plants to "purify" or "cleanse" the body or protect against "poisons of a hot nature." While the former is likely a reflection of West African traditional remedies as discussed above, the latter implies the adoption of European healing beliefs by the slave population and the development of novel pharmacopeias in the region. From a clinicopathological viewpoint, cleansing and cooling remedies could have been used extensively during the period of enslavement due to prevalence of the tropical infectious conditions in the West Indies which affected the inhabitants of the islands. The coast of West Africa, the common site of the embarking of slaves to vessels en route to the Caribbean, was considered a breeding ground for infectious diseases which led to the spread of these conditions in the West Indies (Handler, 2006).

Many of the plant use reports highlighted in this study overlap with those reported in ethnobotanical studies conducted in West Africa and Europe. M. oleifera (Moringa), which informants in this study reported to be useful for hypertension, cough, and diabetes, has been documented for the same traditional uses in both Benin and Ghana (Oppong Bekoe et al., 2020; Agoyi et al., 2014). Additional parallels are seen with $A$. indica (Neem), which is used for diabetes and anti-bacterial purposes both in Nigeria 
and in Barbados, as demonstrated by our findings (Lifongo et al., 2014). In Europe, on the other hand, similar use reports have been found for 1) P. racemosa (Bay Leaf), including headache, upset stomach, and colds, 2) M. charantia (Cerasee), including upset stomach, 3) Mentha x piperita L. (Peppermint), including colds/ flu, and 4) Aloe vera Burm.f. (Aloe), including purgative, cuts and sores (Polat and Satil, 2012; Brussell, 2004; Gonzalez et al., 2010; Leonti et al., 2010). A study carried out in Trinidad and Tobago, a larger island in the south of the Caribbean, has also identified similar botanical families and plant species which can be found in Barbados and were reported to have medicinal properties related to ancestral practices. Stachytarpheta jamaicensis (L.). Vahl, Senna alata (L.) Roxb. and Momordica charantia L. were reported to be widely used for cooling/cleansing in that territory (Clement et al., 2015).

The preponderance of botanical medicine users acquiring knowledge from family members could be related to the rurality of the College Lands' communities. In the post-emancipation era, many liberated slaves migrated to urban centers in pursuit of a better education and achieving middle-class respectability, which meant conforming to British sociopolitical standards. As a result, traditional healing knowledge was largely confined to those who remained in the rural communities (Proctor, 1980). Therefore, the knowledge and use of medicinal plants by persons residing in these communities were likely passed down to them from older generations. This also supports our finding that people with a primary level education were more likely to source medicinal plants from their backyard as compared to those with a secondary level education. In fact, the adoption of western practices, including medicine, by the liberated slaves and their descendants who pursued higher education meant that traditional healing knowledge was essentially relegated the poorer and uneducated population (Proctor, 1980). Studies carried out in Jamaica and Trinidad have found interesting results concerning the relationship between education and the use of botanical medicines. In these studies, the respective prevalence of medicinal plant use among participants was inversely proportional to level of education attained; use was consistently lowest among participants with tertiary education (i.e., post-secondary), and the highest among participants with little to no education (Mahabir and Gulliford, 1997; Merritt-Charles, 2011; Picking et al., 2011). One study investigated the factors affecting the decision to use botanical medicines among asthmatic patients in Trinidad; interestingly, Garlic (Allium sativum L.) and Echinacea (Echinacea purpurea (L.) Moench) were the preferred plant species among users with higher levels of education - both of which have strong scientific evidence supporting their medicinal properties (Clement et al., 2005). In our study, significant differences in the use of botanical medicines were observed between participants with a primary level education and those with associates/vocational degrees. While this is similar to the general trends described above, no difference in use was observed between primary and tertiary (undergraduate/graduate degree) level participants. However, this could be the result of a small sample size or a lack of participants having a tertiary education level in our sample. Additionally, respondents who did not have health insurance were more likely to use botanical medicines than those with health insurance which further supports the socio-economic divide on the use of botanical medicines observed in the Caribbean territories. No significant associations were observed with annual income and the participants that used botanical medicines in this study. However, a modest number of persons identified as users earned an annual income greater than BDS $\$ 28,000.00(n=19)$. This supports a similar trend identified in Trinidad and Tobago where persons in the higher socio-economic class were exposed to the benefits of medicinal plants, but this may be limited to co-modified plant products with strong scientific evidence supporting their medical uses (Clement et al., 2005).

Our finding that combining medicinal plants and prescription medications was less common among people whose parents use medicinal plants could indicate that these participants were mirroring the practices they observed from their parents, whose traditional knowledge and experience may have elucidated some potential risks associated with those practices. A similar element of teaching/learning could be responsible for the observation that the concomitant use of botanical and conventional medicines was less frequent among people who discussed botanical medicines with their doctor. Although the association between age and the use of botanical medicine was not significant in our study, findings from other studies provide support for a general, cross-cultural trend of greater medicinal plant use and knowledge among older individuals and females, as observed in our study (Longuefosse and Nossin, 1996; Begossi et al., 2002; Quinlan and Quinlan, 2007). While the former could be interpreted as evidence of knowledge degradation through the younger generations, the latter may be explained by the notion that women are typically the principal caretakers and health custodians of the household, and in general seem to be more observant of their health than men. In fact, several studies have found that women are more likely to carry out their own forms of health management than are men (Liang et al., 1999; Turner and McClure, 2003; Stjernberg and Berglund, 2005). Interestingly, most participants reported earning an annual income, which may suggest that most of the sample may be employed. Thus, the relatively low gender disparity in botanical medicine use could be the result of more women being in the workforce rather than the sole traditional caretaking role in the household.

The 1969 Health Services Act of Barbados, Cap. 44 and the Drug Services Act 1980 provide the framework which ensures public access to quality drugs under specific categories, especially drugs for chronic non-communicable conditions (CNCDs), at affordable prices to citizens and permanent residents regardless of their socio-economic circumstances (Hennis et al., 2005). As observed in Table 2, persons who reported having one or more CNCDs $(n=95)$ had access to free or reasonable pharmaceutical products to treat their conditions and $75.8 \%$ of these persons were reported users of botanical medicines. This highlights an integration of traditional and westernized healing practices by these individuals as a result of cultural syncretism which may be irrespective of the cost of accessing health care. The lack of association found between the use of botanical medicines and the nature of doctor-patient relationships is also interesting due to the majority of medicinal plant users not discussing this practice with their physicians. It could be that these individuals have internalized the stigma 
surrounding the use of botanical medicines and, in turn, do not discuss it with their physician for fear of being judged or ridiculed. While the majority of respondents would recommend the use of botanical medicines to their peers and family, only a minority were aware of risks associated with the use of these plants as medicines.

These findings support the need for more public education and awareness campaigns on the safe use of botanical medicines. It also highlights the need to archive information about the traditional uses of botanical medicines in a territory with low endemic plant species and diversity coupled with a relatively high burden of medical conditions. While the findings from this study are valuable, there are some limitations. The study data was collected by semi-structured interviews using a validated questionnaire and is likely to be affected by recall bias by the participants. This was evident due to differences in the accuracy and completeness of the recollections retrieved from the study participants on their knowledge and practices on the use of botanical medicines. Also, the use value (UV) and relative frequency of citation (RFC) are dynamic and will vary with changes in locations, the knowledge among the study participants and other factors unique to the study population and their practices. UV determines the extent to which a species can be used; thus, species with a high UV are more exploited in the study area to treat a particular ailment than those with a low UV (Amjad et al., 2017). Data have been analyzed and discussed to highlight comparisons within the dataset and other studies, but this may be limited because of variance and thus should be interpreted with caution. Further, this study was also done in a rural area of Barbados and while these findings may be generalizable to other rural Caribbean areas, they are not generalizable to the whole island of Barbados or urbanised areas of the Caribbean. Finally, field officers collected samples of the plants where possible and these were identified by plant taxonomist at the herbarium at the University of the West Indies, Cave Hill Campus. The identification of the other medicinal plants was by their recognition as crop plants and others were identified by the use of high-resolution photographs of the plants and by the informants' recall. To a lesser extent, some plants were reported as being sourced as semi-processed products, for example, Lactuca virosa Habl. (Wild Lettuce), Oenothera biennis L. (Evening Primrose), Linum usitatissimum L. (Linseed) and Borago officinalis L. (Starflower). Unfortunately, product details inclusive of batch numbers were not able to be retrieved by the interviewers.

\section{CONCLUSION}

The objectives of this study were achieved by the detailed documentation of the knowledge, attitudes, and practices of botanical medicines in rural Barbados, particularly in a district that has never been studied before. Demographic and socioeconomic variables which influence the use of botanical medicines in the surveyed communities were also identified. Additionally, our survey showed the persistence of medico-cultural concepts such as "cooling" and "cleansing" as well as the use of globally recognizable plants, some with West African origins. These findings demonstrate the permeation of ancestral healing practices to persons in these rural communities. Efforts must be mobilized to archive these practices for sensitizing the wider Barbadian and Caribbean population where the use of botanical medicines is much lower. The identification of practices and factors that may influence the use of botanical medicines can promote largerscale studies to help determine how to overcome certain barriers to the use of medicinal plants, as well as to appropriately establish safety and efficacy studies to further evaluate the pharmacological effects of traditional plant-based remedies.

\section{DATA AVAILABILITY STATEMENT}

The raw data supporting the conclusions of this article will be made available by the authors.

\section{ETHICS STATEMENT}

The studies involving human participants were reviewed and approved by University of the West Indies/Barbados Ministry of Health Ethics Committee/Institutional Review Board (IRB No. 180303-A). Written informed consent by informants was provided prior to their participation. This includes written informed consent by the participants' legal guardian/next of kin as required.

\section{AUTHOR CONTRIBUTIONS}

DC designed and conducted the survey, reviewed and assisted with the writing and editing of the manuscript. TV carried out all data analyses and wrote the manuscript.

\section{FUNDING}

This study was funded by the UNOPS GEF Small Grants Programme (BAR/SGP/OP6/Y3/CORE/BD/17/02).

\section{ACKNOWLEDGMENTS}

To Michael Clarke, Principal of Codrington College, for support with the study. To Professor Sean Carrington, Taxonomist at The University of the West Indies, for his assistance with the identification and vouchering of the plant samples.

\section{SUPPLEMENTARY MATERIAL}

The Supplementary Material for this article can be found online at: https://www.frontiersin.org/articles/10.3389/fphar.2021.713855/ full\#supplementary-material 


\section{REFERENCES}

Abrahams, R. D. (1967). The Shaping of Folklore Traditions in the British West Indies. J. Inter-am. Stud. 9 (3), 456-480. doi:10.2307/164803

Agoyi, E. E., Assogbadjo, A. E., Gouwakinnou, G., Okou, F. A. Y., and Sinsin, B. (2014). Ethnobotanical Assessment of Moringa Oleifera Lam. In Southern Benin (West Africa). Ethnobot. Res. App. 12, 551-560. doi:10.17348/ era.12.0.551-560

Amjad, M. S., Qaeem, M. F., Ahmad, I., Khan, S. U., Chaudhari, S. K., Zahid Malik, N., et al. (2017). Descriptive Study of Plant Resources in the Context of the Ethnomedicinal Relevance of Indigenous flora: A Case Study From Toli Peer National Park, Azad Jammu and Kashmir, Pakistan. PLOS One 12 (2), e0171896. doi:10.1371/journal.pone.0171896

Andriamparany, J. N., Brinkmann, K., Jeannoda, V., and Buerkert, A. (2014). Effects of Socio-Economic Household Characteristics on Traditional Knowledge and Usage of Wild Yams and Medicinal Plants in the Mahafaly Region of South-Western Madagascar. J. Ethnobiol. Ethnomed. 10 (82), 82. doi:10.1186/1746-4269-10-82

Bayley, I. (1949). The Bush Teas of Barbados. J. Barbados Must Hist. Soc. 16, 103-105.

Begossi, A., Hanazaki, N., and Tamashiro, J. Y. (2002). Medicinal Plants in the Atlantic Forest (Brazil): Knowledge, Use and Conservation. Hum. Ecol. 30 (3), 281-299. doi:10.1023/a:1016564217719

Carrington, S. (2007). Wild Plants of Barbados. 2nd ed. Oxford, England: Macmillan Caribbean.

Clement, Y. N., Baksh-Comeau, Y. S., and Seaforth, C. E. (2015). An Ethnobotanical Survey of Medicinal Plants in Trinidad. J. Ethnobiol. Ethnomed. 11, 67. doi:10.1186/s13002-015-0052-0

Clement, Y. N., Williams, A. F., Aranda, D., Chase, R., Watson, N., Mohammed, R., et al. (2005). Medicinal Herb Use Among Asthmatic Patients Attending a Specialty Care Facility in Trinidad. BMC Complement. Altern. Med. 5 (1), 3. doi:10.1186/1472-6882-5-3

Cohall, D. H. (2014). Medicinal Plants of Barbados for the Treatment of Communicable and Non-Communicable Diseases. Kingston, Jamaica: University of the West Indies Press.

Cohall, D. H., Scantlebury-Manning, T., Cadogan-McLean, C., Lallement, A., and Willis-O'Connor, S. (2012). The Impact of the Healthcare System in Barbados (Provision of Health Insurance and the Benefit Service Scheme) on the Use of Herbal Remedies by Christian Churchgoers. West. Indian Med. J. 61 (3), 258-263. doi:10.7727/wimj.2011.178

Cook, H. J., and Walker, T. D. (2013). Circulation of Medicine in the Early Modern Atlantic World. Soc. Hist. Med. 26 (3), 337-351. doi:10.1093/shm/hkt013

Crawford-Daniel, W. Y., and Alexis, J. M. (2014). in Caribbean Healing Traditions: Implications for Health and Mental Health. Editors P. Sutherland, R. Moodley, and B. Chevannes (New York (NY): Routledge), 29-40.

Eric Brussell, D. (2004). Medicinal Plants of MT. Pelion, Greece. Econ. Bot. 58 (S), S174-S202. doi:10.1663/0013-0001(2004)58[s174:mpompg]2.0.co;2

Feng, P. C. (1956). A Preliminary Survey of the Medicinal Plants of British Guiana. West. Indian Med. J. 5 (4), 265-270.

Global Burden of Disease Collaborative Network (2020). Global Burden of Disease Study 2019 (GBD 2019). Seattle, United States of America: Institute for Health Metrics and Evaluation.

González, J. A., García-Barriuso, M., and Amich, F. (2010). Ethnobotanical Study of Medicinal Plants Traditionally Used in the Arribes del Duero, Western Spain. J. Ethnopharmacol. 131 (2), 343-355. doi:10.1016/j.jep.2010.07.022

Handler, J. S. (2006). Diseases and Medical Disabilities of Enslaved Barbadians, From the Seventeenth Century to Around 1838: Part 1. Caribbean J. Hist. 40, 1-38.

Handler, J. S., and Jacoby, J. A. (1993). Slave Medicine and Plant Use in Barbados. J. Barbados Mus. Hist. Soc. 41, 76-98.

Hennis, A., Hambleton, I., Crichlow, S., and Fraser, H. (2005). Health, Welfare and Aging in Bridgetown, Barbados. Washington, DC: SABE 2000.

Heredia-Diaz, Y., Garcia-Diaz, J., Lopez-Gonzalez, T., Chil-Nunez, I., AriasRamos, D., Escalona-Arranz, J. C., et al. (2018). An Ethnobotanical Survey of Medicinal Plants Used by Inhabitants of Holguin, Eastern Region, Cuba. Bol Latinoam. Caribe Plantas Med. Aromat. 15 (2), 160-196.

Holder, J. W. (1988). Codrington College - A Brief History. Bridgetown. Barbados: Codrington College.
Jackson, C. S., Phillips, A. D. V., and Marshall, W. K. (2021). Barbados. Encyclopedia Brittanica. Available at: https://www.britannica.com/place/ Barbados (Accessed June 28, 2021).

Labonté, R., Runnels, V., Crooks, V. A., Johnston, R., and Snyder, J. (2017). What Does the Development of Medical Tourism in Barbados Hold for Health Equity? an Exploratory Qualitative Case Study. Glob. Health Res. Pol. 2, 5. doi:10.1186/s41256-017-0025-z

Lane, A. (1979). Race, Class and Development in Barbados. Caribbean Q. 25 (1/2), 45-51. doi:10.1080/00086495.1979.11671944

Leonti, M., Cabras, S., Weckerle, C. S., Solinas, M. N., and Casu, L. (2010). The Causal Dependence of Present Plant Knowledge on HerbalsCcontemporary Medicinal Plant Use in Campania (Italy) Compared to Matthioli (1568). J. Ethnopharmacol. 130 (2), 379-391. doi:10.1016/ j.jep.2010.05.021

Liang, W., Shediac-Rizkallah, M. C., Celentano, D. D., and Rohde, C. (1999). A Population-Based Study of Age and Gender Differences in Patterns of HealthRelated Behaviors. Am. J. Prev. Med. 17, 8-17. doi:10.1016/s0749-3797(99) 00040-9

Lifongo, L. L., Simoben, C. V., Ntie-Kang, F., Babiaka, S. B., and Judson, P. N. (2014). A Bioactivity versus Ethnobotanical Survey of Medicinal Plants from Nigeria, West Africa. Nat. Prod. Bioprospect. 4, 1-19. doi:10.1007/s13659-0140005-7

Longuefosse, J. L., and Nossin, E. (1996). Medical Ethnobotany Survey in Martinique. J. Ethnopharmacol. 53 (3), 117-142. doi:10.1016/0378-8741(96) 01425-0

Mahabir, D., and Gulliford, M. C. (1997). Use of Medicinal Plants for Diabetes in Trinidad and Tobago. Rev. Panam Salud Publica. 1 (3), 174-179. doi:10.1590/ s1020-49891997000300002

McCaskie, T. C. (2017). "The Art or Mystery of Physick" - Asante Medicinal Plants and the Western Ordering of Botanical Knowledge. Hist. Afr. 44, 27-62. doi:10.1017/hia.2016.11

Merritt-Charles, L. (2011). The Prevalence of Herbal Medicine Use Among Surgical Patients in Trinidad. Focus Altern. Complement. Ther. 16 (4), 266-270. doi:10.1111/j.2042-7166.2011.01121.x

Napagoda, M. T., Sundarapperuma, T., Fonseka, D., Amarasiri, S., and Gunaratna, P. (2018). An Ethnobotanical Study of the Medicinal Plants Used as Anti-Inflammatory Remedies in Gampaha District, Western Province, Sri Lanka. Scientifica (Cairo). 2018, 9395052-9395058. doi:10.1155/2018/9395052

Oppong Bekoe, E., Agyare, C., Boakye, Y. D., Baiden, B. M., Asase, A., Sarkodie, J., et al. (2020). Ethnomedicinal Survey and Mutagenic Studies of Plants Used in Accra metropolis, Ghana. J. Ethnopharmacol. 248, 112309. doi:10.1016/ j.jep.2019.112309

Peter, S. (2013). "Medicinal and Cooling Teas of Barbados," in African Ethnobotany in the Americas. Editors R. Voeks and J. Rashford (New York, NY: Springer). doi:10.1007/978-1-4614-0836-9_11

Phillips, O., and Gentry, A. H. (1993). The Useful Plants of Tambopata, Peru: I. Statistical Hypotheses Tests With a New Quantitative Technique. Econ. Bot. 47 (1), 15-32. doi:10.1007/bf02862203

Picking, D., Delgoda, R., Younger, N., Germosén-Robineau, L., Boulogne, I., and Mitchell, S. (2015). TRAMIL Ethnomedicinal Survey in Jamaica. J. Ethnopharmacol. 169, 314-327. doi:10.1016/j.jep.2015.04.027

Picking, D., Younger, N., Mitchell, S., and Delgoda, R. (2011). The Prevalence of Herbal Medicine Home Use and Concomitant Use With Pharmaceutical Medicines in Jamaica. J. Ethnopharmacol. 137 (1), 305-311. doi:10.1016/ j.jep.2011.05.025

Polat, R., and Satıl, F. (2012). An Ethnobotanical Survey of Medicinal Plants in Edremit Gulf (Balıkesir-Turkey). J. Ethnopharmacol. 139 (2), 626-641. doi:10.1016/j.jep.2011.12.004

Prasad, S., Sung, B., and Aggarwal, B. B. (2012). Age-Associated Chronic Diseases Require Age-Old Medicine: Role of Chronic Inflammation. Prev. Med. 54, S29-S37. doi:10.1016/j.ypmed.2011.11.011

Proctor, R. (1980). Early Developments in Barbadian Education. J. Negro Education 49 (2), 184. doi:10.2307/2294967

Quinlan, M. B., and Quinlan, R. J. (2007). Modernization and Medicinal Plant Knowledge in a Caribbean Horticultural Village. Med. Anthropol. Q. 21 (2), 169-192. doi:10.1525/maq.2007.21.2.169 
Soelberg, J., Davis, O., and Jäger, A. K. (2016). Historical versus Contemporary Medicinal Plant Uses in the US Virgin Islands. J. Ethnopharmacol. 192, 74-89. doi:10.1016/j.jep.2016.07.005

Stjernberg, L., and Berglund, J. (2005). Tick Prevention in a Population Living in a Highly Endemic Area. Scand. J. Public Health. 33, 432-438. doi:10.1080/14034940510005932

Sutherland, P., Moodley, R., and Chevannes, P. (2013). Caribbean healing traditions: Implications for health and mental health. 1st ed. New York: Routledge.

Tareau, M. A., Palisse, M., and Odonne, G. (2017). As Vivid as a Weed... Medicinal and Cosmetic Plant Uses Amongst the Urban Youth in French Guiana Medicinal and Cosmetic Plant Uses Among the Urban Youth in French Guiana. J. Ethnopharmacol. 203, 200-213. doi:10.1016/j.jep.2017.03.031

Torres-Avilez, W., Méndez-González, M., Durán-García, R., Boulogne, I., and Germosén-Robineau, L. (2015). Medicinal Plant Knowledge in Caribbean Basin: A Comparative Study of Afrocaribbean, Amerindian and Mestizo Communities. J. Ethnobiol. Ethnomed. 11 (18), 18. doi:10.1186/s13002-015-0008-4

Turner, C., and McClure, R. (2003). Age and Gender Differences in Risk-Taking Behaviour as an Explanation for High Incidence of Motor Vehicle Crashes as a Driver in Young Males. Inj. Control. Saf. Promot. 10, 123-130. doi:10.1076/ icsp.10.3.123.14560

Unwin, N., Rose, A. M. C., George, K. S., Hambleton, I. R., and Howitt, C. (2015). The Barbados Health of the Nation Survey: Core Findings. St. Michael, Barbados: Barbados Ministry of Health and Chronic Disease Research Centre, The University of the West Indies. Available at: http://www.archive. healthycaribbean.org/newsletters/aug-2015/CDRC_HealthOfTheNationSurvey. pdf (Accessed May 27, 2021).
Vandebroek, I., and Picking, D. (2020). Popular Medicinal Plants in Portland and Kingston, Jamaica. New York (NY): Springer International Publishing.

Watts, D. H. (1966). Man's Influence on the Vegetation of Barbados. Yorkshire (England): University of Hull Publications, 1627-1800.

White, P. (2015). The Concept of Diseases and Health Care in African Traditional Religion in Ghana. HTS Teol. Stud. 71 (3), a2762. doi:10.4102/HTS.V71I3.2762

World Development Indicators (2019). The World Bank. Available at https:// datacommons.org/place/country/BRB?utm_medium $=$ explore\&mprop $=$ count \&popt=Person\&hl=en (Accessed June 28, 2021).

Conflict of Interest: The authors declare that the research was conducted in the absence of any commercial or financial relationships that could be construed as a potential conflict of interest.

Publisher's Note: All claims expressed in this article are solely those of the authors and do not necessarily represent those of their affiliated organizations, or those of the publisher, the editors and the reviewers. Any product that may be evaluated in this article, or claim that may be made by its manufacturer, is not guaranteed or endorsed by the publisher.

Copyright (c) 2021 Vujicic and Cohall. This is an open-access article distributed under the terms of the Creative Commons Attribution License (CC BY). The use, distribution or reproduction in other forums is permitted, provided the original author(s) and the copyright owner(s) are credited and that the original publication in this journal is cited, in accordance with accepted academic practice. No use, distribution or reproduction is permitted which does not comply with these terms. 